\title{
11. Financial Reform in Australia and China
}

Alexander Ballantyne, Jonathan Hambur, Ivan Roberts and Michelle Wright ${ }^{1}$

\section{Introduction}

The financial architecture currently in place in the People's Republic of China shares some characteristics with Australia's financial system prior to deregulation in the late 1970s and early 1980s. In the late 1970s, Australia maintained a managed exchange rate regime, capital account transactions were subject to restrictions and the banking system was tightly regulated. Taken at face value, this is similar to China today, where portfolio capital flows are largely prohibited, the renminbi exchange rate continues to be managed and banking sector interest rates are only partially liberalised.

Naturally, there are important differences as well. Australia's weight in the global economy was smaller and its financial reforms occurred in the context of a much smaller and less integrated global financial system. While its capital account in the 1970s and early 1980s was more tightly restricted than other similar economies, Australia was somewhat more open to foreign portfolio investment than China is currently. China receives relatively larger direct investment flows today than Australia did prior to capital account liberalisation. In addition, parts of the Chinese financial system are now more developed than the Australian financial system was prior to financial deregulation.

Notwithstanding these differences, the Australian example serves to underscore both the potential importance of sequencing and the powerful catalytic effects of a decision to liberalise. The floating exchange rate is now widely recognised as having played a crucial role in helping to steer the economy through challenging periods (Beaumont and Cui 2007; Stevens 2013). Nevertheless, the full benefits of financial deregulation, the float and capital

1 The authors are from the International and Economic Research departments at the Reserve Bank of Australia. The discussion of financial reform in Australia in this chapter has benefited greatly from unpublished research by Lynne Cockerell. The authors would like to thank Chris Ryan, Alexandra Heath, James Holloway and Chris Becker for numerous helpful comments and suggestions. The views expressed in this chapter are the authors' own and do not necessarily reflect those of the Reserve Bank of Australia. The authors are solely responsible for any errors. 
account liberalisation were not fully realised until economic agents had adapted, markets had developed and the credibility of Australia's economic policy framework and institutions had been established.

Although there had been efforts to deregulate the banking system in the 1970s, this process was not completed until after the float of the exchange rate and the liberalisation of the capital account. The combination of a newly liberalised financial sector and capital account exposed Australia's underdeveloped prudential regulation framework and banks' relative inexperience in the pricing of risk. This, in turn, led to an unsustainable boom in credit in the 1980s, followed by a sharp correction and significant effects on the real economy. Similarly, while foreign exchange markets had started to develop prior to the float, it was only after agents were subjected to greater exchange rate volatility and the discipline of a free market - underpinned by credible institutions and economic policies - that Australia's hedging and foreign exchange markets could fully develop.

China's own process of economic reform and opening began in the late 1970s. Its transition from a centrally planned economy began with the reform of agricultural and industrial product markets, and proceeded to the opening of external trade, the domestic corporate sector, and later the urban labour and property markets. Financial reform has occurred more slowly. In the late 1990s, the authorities began a process of gradually liberalising interest rates on loans that culminated in the removal of nearly all such restrictions in 2013. Deposit rates, however, have yet to be fully liberalised. Since 2005, China's renminbi-US dollar exchange rate has gradually become more flexible, although it continues to be managed closely by the authorities.

In recent years, the optimal sequencing of China's financial reform has been a subject of much discussion. The liberalisation of domestic interest rates, the exchange rate and the capital account have all been on the formal agenda of regulators since the early 2000s (PBC 2003; Zhou 2005) and were listed as national priorities in the Eleventh and Twelfth Five-Year Plans (Government of the People's Republic of China 2005, 2011) and the Third Plenum of the Chinese Communist Party in 2013 (CCP 2013). But within Chinese policy circles, the debate over China's future financial reforms has been polarised.

Some observers have advised China against prioritising the removal of capital controls on the basis that the domestic financial infrastructure and regulation framework are insufficiently developed to open the economy to short-term capital flows (Yu 2013). The deterioration in the quality of banking sector assets since China's policy stimulus during the GFC, rising corporate and local government debt and the expansion of off-balance sheet activities by banks are cited as reasons for delaying capital account convertibility. It is argued that 
domestic financial deregulation and increased exchange rate flexibility should happen first if the liberalisation of short-term capital flows is to occur in a nondestabilising manner (He 2013).

Others have called for the Chinese capital account to be liberalised within five to 10 years, on the grounds that China's large foreign exchange reserves, low foreign debt and the current absence of currency mismatches on the balance sheets of banks greatly lower the risk that speculative flows will create financial instability (PBC Department of Surveys and Statistics Task Force 2012a, 2012b). According to this argument, capital account liberalisation should proceed in conjunction with efforts to complete domestic interest rate deregulation and free floating of the exchange rate. Prioritising interest rate deregulation over capital account convertibility and currency flexibility is viewed as unnecessary: reform can be focused on one area until a certain stage of maturity is reached, and redirected towards another. The People's Bank of China (PBC) Department of Surveys and Statistics Task Force (2012b) contends that the historical experiences of Japan, South Korea, the United States, the United Kingdom and Germany do not support an interpretation that domestic financial deregulation must precede liberalisation of the capital account.

In general, the literature on the sequencing of financial reform tends to prioritise domestic financial reform and exchange rate flexibility ahead of capital account liberalisation. Based on numerous case studies, McKinnon (1982, 1991) argues that the development of domestic financial institutions, markets and instruments is a prerequisite for successfully liberalising the capital account, and that therefore capital account liberalisation should occur at a relatively late stage in the reform process. While stressing that a sound system of domestic financial regulation should be prioritised, Johnston (1998) notes that early capital account liberalisation can have an important catalytic role in broader economic reforms, and can help overcome entrenched vested interests that otherwise postpone necessary reforms. Ishii and Habermeier (2002) propose that, to avoid instability, longer-term capital flows - particularly foreign direct investment (FDI) flows - should be liberalised before shortterm flows. Fry (1997) emphasises that the successful removal of interest rate ceilings requires certain preconditions to be met, including adequate prudential regulation and supervision of commercial banks.

This chapter contributes to discussions of financial liberalisation in comparative financial systems. It follows a substantial literature studying Australian financial deregulation (Battellino and McMillan 1989; Grenville 1991; Debelle and Plumb 2006; Battellino and Plumb 2011) and financial reform in China (McKinnon 1994; Lardy 1998; Prasad and Wei 2005; Prasad et al. 2005; Allen et al. 2012; Huang et al. 2013; Eichengreen et al. 2014). It should be emphasised, however, that this chapter does not interpret Australia's 
experience as a prescription for China. Indeed, it emphasises the differences in initial conditions and aspects of Australia's financial arrangements, which the 'sequencing' literature would consider, prior to reform, as suboptimal. The chapter also stresses the interdependence between financial reform and financial deepening.

The chapter proceeds as follows. The next section discusses Australia's historical experience with financial deregulation. We then consider China's financial reforms to date and itemise the restrictions that currently affect interest rates, the exchange rate and capital flows. We then outline differences and similarities in the Australian and Chinese experiences, before offering some concluding remarks.

\section{Australia's experience with financial reform}

Prior to the float of the Australian dollar in 1983, Australia made a gradual transition through a series of increasingly flexible exchange rate regimes. This transition was related closely to the development of Australian financial markets - including closer integration with global financial markets - which made it increasingly difficult for the authorities to manage the exchange rate and control domestic monetary conditions. The authorities responded to these challenges with a series of financial reforms throughout the 1970s and 1980s.

\section{The 1950s and 1960s}

Prior to the 1970s, Australia had a fixed exchange rate regime, which was underpinned by a system of capital controls and a highly regulated domestic banking sector. Although the domestic banking sector remained underdeveloped, the prevailing view of policymakers was that the fixed exchange rate had been beneficial. Australia's generally strong postwar economic performance provided little evidence against this view. And with global financial integration still in its infancy under the Bretton Woods system, there was relatively little pressurefor example, from waves of capital inflows and outflows - to deviate from the established framework.

\section{The fixed exchange rate regime and system of capital controls}

From 1931 until the early 1970s, Australia's currency was pegged to the British pound sterling. There were no significant exchange controls in place during most of the 1930s, but in subsequent years the fixed exchange rate was underpinned by a comprehensive system of exchange controls, which were first introduced as emergency measures during World War II (Phillips 1985; Laker 1988). Under this 
system, all foreign currency transactions were prohibited unless approved or specifically exempted by the Reserve Bank of Australia (RBA), and participation in the foreign exchange market was restricted to designated 'trading' banks, which acted as agents for the RBA.

In practice, however, foreign exchange transactions related to trade and most current receipts were generally approved by the RBA, as were private capital inflows and repatriations of capital by foreign investors. That is, while the system of exchange controls had the potential to be quite restrictive, it was applied in a more permissive manner. This relatively permissive approach to inflows (and outflows) of foreign capital was consistent with a broader recognition by policymakers of the important role played by foreign investment in Australia's economic development. In contrast, Australian investment abroad was heavily restricted, reflecting the authorities' preference for domestic savings to be channelled into domestic investment (Battellino 2007).

The asymmetric nature of Australia's system of exchange controls was reflected in the composition of Australia's capital flows. Australian investment abroad by the 'non-official' sector was virtually nonexistent during the 1950s and 1960s, averaging just 0.2 per cent of GDP throughout this period, compared with an average of around 2 per cent in the decade after the float and removal of capital controls in 1983. In contrast, foreign investment in Australia's nonofficial sector averaged around 2.5 per cent of GDP during the 1950s and 1960s and around 6 per cent of GDP in the decade after the float. ${ }^{2}$

To maintain the peg to the UK pound, these net inflows of foreign capital were offset, as required, by outflows of official capital in the form of foreign exchange reserve accumulation. This was reflected in fairly consistent net outflows of capital from the RBA in the 1950s and 1960s, and indeed until the mid 1970s (Figure 11.1). ${ }^{3}$

2 Unless otherwise stated, Australian historical data are sourced from the Australian economic statistics - 1949-1950 to 1996-1997, which were originally published as Occasional Paper No. 8 and are now available from: <http://www.rba.gov.au/statistics/frequency/occ-paper-8.html>.

3 One notable exception was 1952-53, which coincided with the end of the Korean War and the related wool price boom and a large rise in net exports. For more information, see Atkin et al. (2014). 


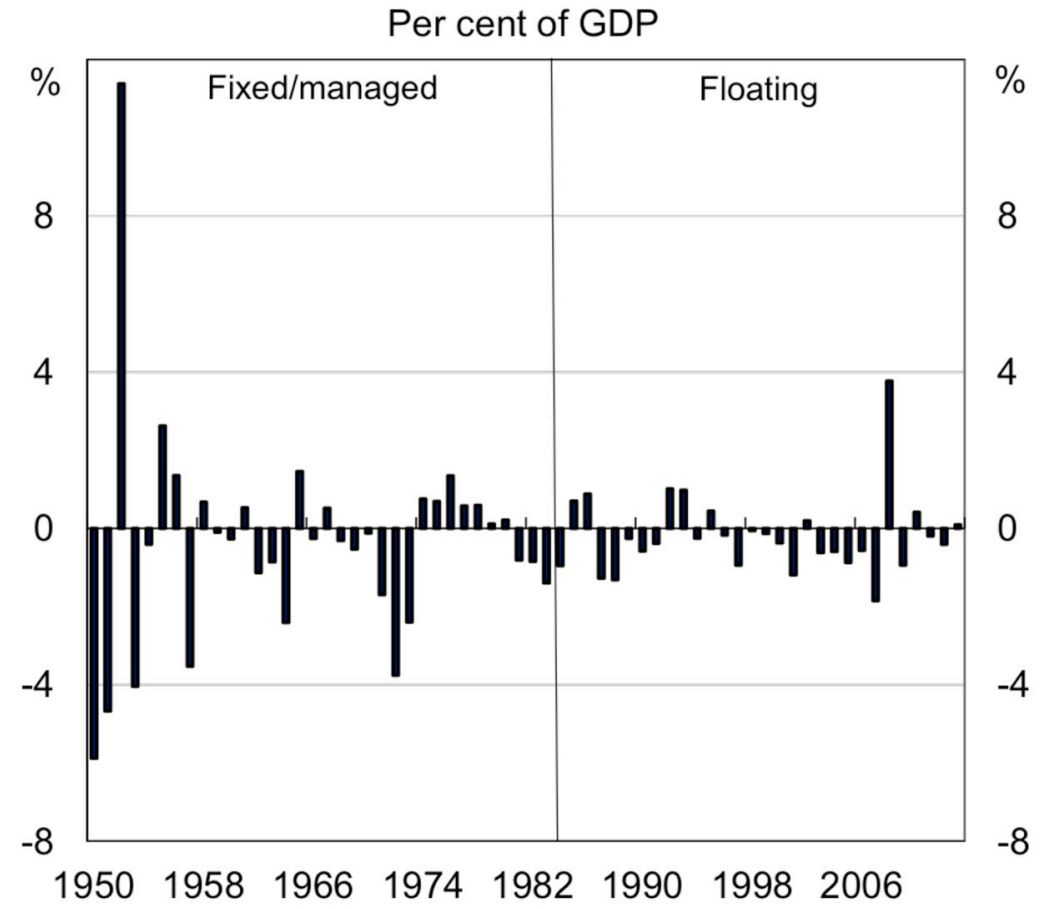

Figure 11.1 Net Capital Inflows to the RBA

Sources: Australian Bureau of Statistics (ABS); The Reserve Bank of Australia (RBA).

\section{Domestic banking sector regulation}

Australia also had a heavily regulated domestic banking sector, with quantitative and qualitative controls on bank lending, ceilings on banks' deposit and lending rates and reserve requirements all used. ${ }^{4}$ These regulations, especially the reserve requirements, also served as the main tools for implementing monetary policy for much of the 1950s, 1960s and 1970s.

In addition to serving prudential and monetary policy purposes, these regulations also helped to maintain Australia's fixed exchange rate system by limiting capital inflows to the banking sector. For example, ceilings on deposit

4 For more detailed information on these regulations, see Grenville (1991) and Battellino and McMillan (1989). 
rates limited the ability of domestic trading banks to attract overseas funding, while domestic savings banks were effectively unable to raise funds from overseas as they were not permitted to use wholesale funding. ${ }^{5}$

At the same time, however, heavy regulation of the banking sector impeded the sector's development. The ratio of bank assets to GDP stood at around 50 per cent in 1975, compared with around 200 per cent today. In comparison, the ratio of UK bank assets to GDP was higher in 1975, at around 100 per cent (Davies et al. 2010). Banks also had little experience in trading in foreign exchange markets, having been permitted to trade only as principals in the market from 1971 - and then only in the context of a fixed exchange rate regime. ${ }^{6}$

The underdeveloped state of Australia's financial sector was an important consideration in the authorities' decision to retain a fixed exchange rate regime when the Bretton Woods system broke down in the early 1970s (Phillips 1984a). In contrast with most other present-day developed economies, which chose to adopt a more flexible exchange rate regime around this time, the Australian Government decided instead to simply replace the peg to the pound sterling with a peg to the US dollar (in recognition of the increased importance of the United States as a trading partner).

\section{The 1970s}

Maintaining the fixed exchange rate regime became more challenging in the late 1960s and early 1970s, as non-official capital inflows became larger and more varied in nature (Figure 11.2). In particular, the combination of larger capital flows, a growing non-bank financial sector and structural issues with the government debt market undermined the effectiveness of monetary policy (Grenville 1991). As a result, the authorities found it increasingly difficult to control domestic monetary conditions.

5 Broadly, savings banks lent to households and trading banks lent to businesses. While savings banks could accept deposits only from households and non-profit organisations, trading banks could raise wholesale deposits. Both were subject to a number of 'reserve requirements'; however, the requirements on savings banks were more stringent. For more information, see Battellino and McMillan (1989).

6 Before 1971, banks were only permitted to trade as agents of the RBA. 


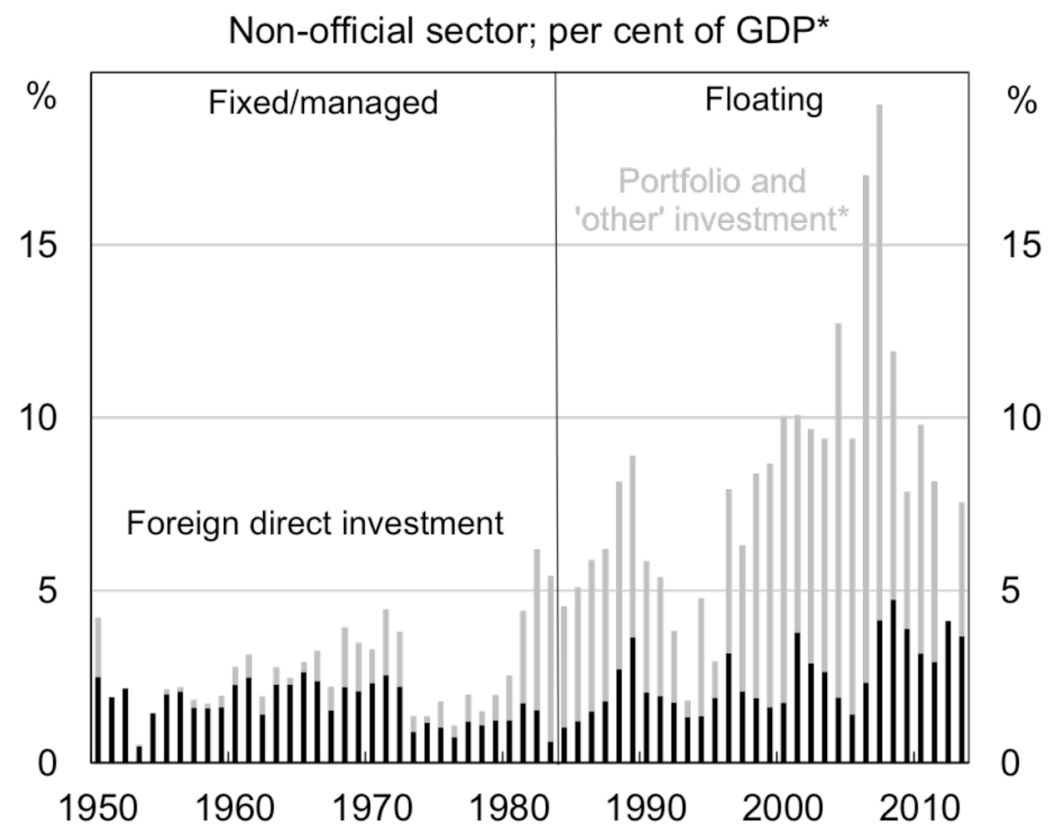

Figure 11.2 Australian Gross Capital Inflows

Sources: Australian Bureau of Statistics (ABS); The Reserve Bank of Australia (RBA).

Notes: Examples of 'other' investment flows are loans, deposits and accounts payable/receivable. Excludes financial derivatives where data are available.

The growth in the non-bank financial sector - which was fuelled partly by increased capital inflows - prompted the authorities to take initial steps towards banking sector deregulation. In many ways, this laid the groundwork for the eventual float of the exchange rate a decade later. Banking sector deregulation not only increased the challenges associated with capital flow managementarguably accelerating the transition from a fixed to a floating exchange rate regime-but it also facilitated domestic financial market development and innovation, laying the foundations for market participants to adapt to the new regime.

\section{Capital flow management challenges}

Australia experienced a period of noticeably larger capital inflows during the late 1960s and early 1970s - which coincided with a domestic mining boomwith gross capital inflows to the 'non-official' sector averaging almost 4 per cent of GDP in the five years to 1971-72, up from 2.5 per cent in the previous five years. Further, these flows increasingly arrived in the form of portfolio and 'other' - rather than direct-investment, which accounted for an average of 40 per cent of Australia's gross capital inflows in the five years to 1971-72, 
up from 20 per cent in the previous five years. ${ }^{7}$ This shift in the composition of capital inflows was facilitated partly by an influx of international merchant banks into the Australian market, which increased domestic companies' awareness of, and access to, overseas capital (Australian Treasury 1999). ${ }^{8}$

These larger capital inflows made it increasingly difficult for the authorities to control domestic monetary conditions. Under the fixed exchange rate system, capital inflows added directly to domestic liquidity (and vice versa for capital outflows), as the RBA was obliged to meet all demand for Australian dollars at the official rate. While the authorities could (and did) attempt to sterilise the impact of the additional liquidity by changing reserve requirements on banks, this mechanism became less effective as banks lost market share to non-bank financial institutions. Authorities also could (and did) attempt to sterilise the additional liquidity via domestic market operations, but this often led to higher interest rates, which could then encourage further inflows. The effectiveness of open market operations as a liquidity management tool was further hampered by structural issues associated with the market for government securities. ${ }^{9}$

Early steps in the deregulation of the banking sector (discussed further below) compounded the effects of this additional liquidity on the domestic economy. In particular, the removal of quantitative controls on bank lending in 1971, and the removal of interest rate ceilings on large loans in early 1972, allowed banks to profitably lend these additional funds. Further, the removal of the ceiling on interest rates payable on certificates of deposit (CDs) in 1973 allowed banks to compete more effectively for these funds. These factors contributed to a large increase in the rate of growth in bank lending, which reached more than 30 per cent in year-ended terms in 1973 (Figure 11.3).

7 'Other' investment primarily consists of loans (including trade credit) and deposits.

8 Many of these merchant banks entered the Australian market with the intention of funding mining projects that, due to regulations, could not be funded by domestic banks.

9 These included procedural issues associated with the 'tap' system of primary issuance for government securities, as well as issues associated with banks' large 'captive' holdings of government securities. For more information, see Grenville (1991). 


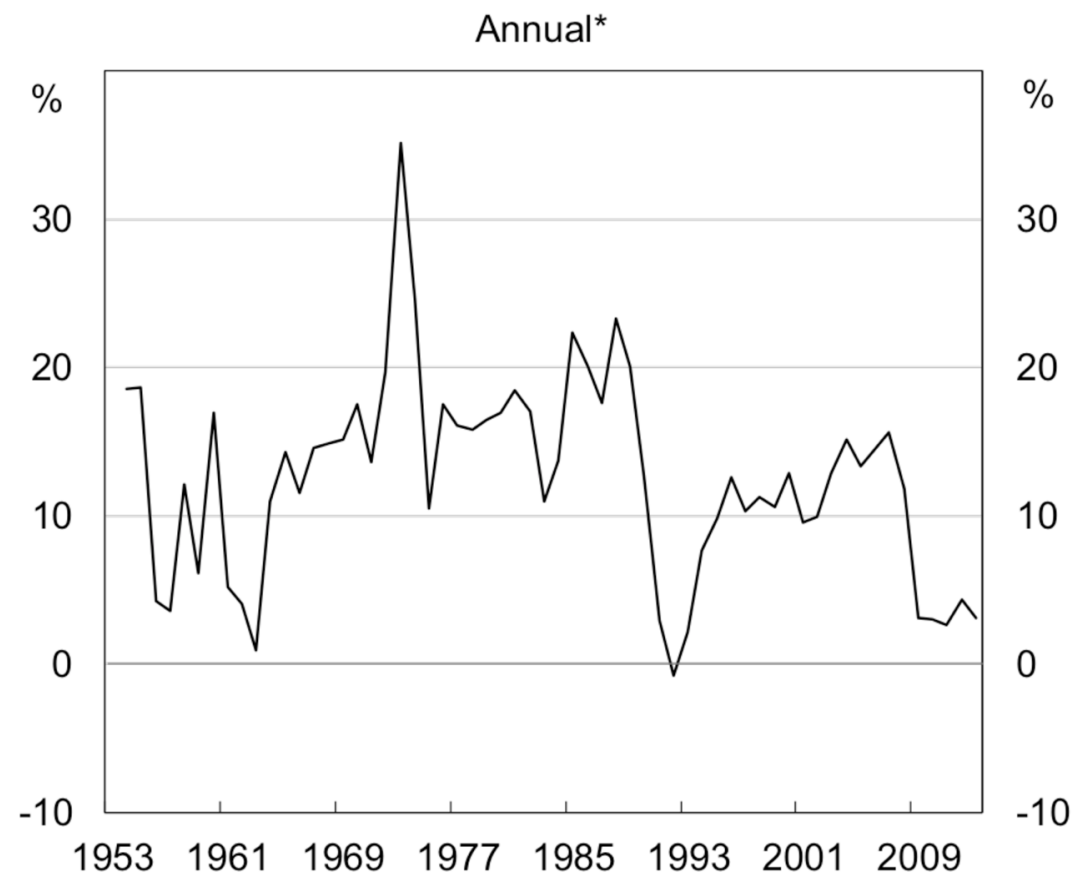

Figure 11.3 Australian Domestic Credit Growth

Source: The Reserve Bank of Australia (RBA).

Note: Series are break and seasonally adjusted where available.

\section{The policy response}

In response to these large portfolio inflows - and more specifically, to the effects of these flows on domestic liquidity and credit growth - the authorities revalued the Australian dollar by 7 per cent against the US dollar in late 1972 . A number of 'supplementary' exchange controls were also introduced, including an embargo on loans from overseas with a maturity of less than two years and a variable deposit requirement (VDR) for overseas loans with a maturity greater than two years. The VDR was preferred over other forms of capital control as it was considered to be a more 'market-based' mechanism (Australian Treasury 1999).

The VDR initially required 25 per cent of overseas borrowings to be placed in an interest-free account at the RBA, which effectively acted as a tax. The measures were considered to be largely successful, contributing to a marked contraction in capital inflows, particularly portfolio inflows, and a sharp tightening in domestic monetary conditions (Australian Treasury 1999; 
Debelle and Plumb 2006). Over the following decade, a number of changes were made to the VDR and the embargo in response to changes in the volume and composition of Australian capital flows.

Around the same time, authorities began to deregulate the banking sector. The move towards deregulation was prompted by a decline in the sector's market share, as banks found it increasingly difficult to compete with non-bank financial institutions (NBFIs). As NBFIs were not subject to the same stringent regulations as banks, they were able to compete more aggressively for funding and were able to provide loans to a broader range of borrowers (including riskier ones).

The growth of the NBFI sector diminished the effectiveness of monetary policy by lessening the economic impact of changes in bank reserve requirements, interest rate ceilings and credit directives. ${ }^{10}$ While some policymakers favoured extending regulation to the NBFI sector, there was a growing consensus in favour of more market-oriented policies, rather than direct controls (Phillips 1984b). Consequently, the decision was made to remove some of the controls on banks' balance sheets and to attempt to transmit monetary policy through the general level of interest rates - which would in turn be influenced by the RBA's open market operations. ${ }^{11}$

The first major step in the deregulation of the banking sector was taken in 1973, when the interest rate ceiling on CDs was removed. This allowed trading banks to compete for funds and gave them control over a larger portion of their balance sheets. ${ }^{12}$ In particular, it allowed them to manage their liabilities more actively, which has subsequently been cited as having played a crucial role in preparing banks for the larger capital flows that were ultimately associated with capital account liberalisation in the early 1980s (Battellino and McMillan 1989).

10 The effectiveness of monetary policy was further diminished by banks' increasing use of the bank bill market, which was off-balance sheet and was regulated less heavily (Grenville 1991).

11 This shift in the approach to monetary policy implementation was facilitated by a lower level of government debt - which had declined to 30 per cent of GDP by 1970, from 100 per cent in 1950 - and the authorities' greater readiness to accept changes in interest rates (Grenville 1991).

12 Savings banks were still constrained by interest rate ceilings on housing loans and the prohibition on raising wholesale deposits. Consequently, their behaviour was largely unchanged in response to the removal of interest rate ceilings on CDs (Battellino and McMillan 1989). 
The market response

Despite these policy changes, the Australian dollar's peg to the US dollar continued to be difficult to maintain. Following a number of upward revaluations in the early 1970s, the US dollar peg was replaced with a peg to a trade-weighted basket of currencies in 1974, at a rate that implied a 12 per cent devaluation against the US dollar (Figure 11.4).

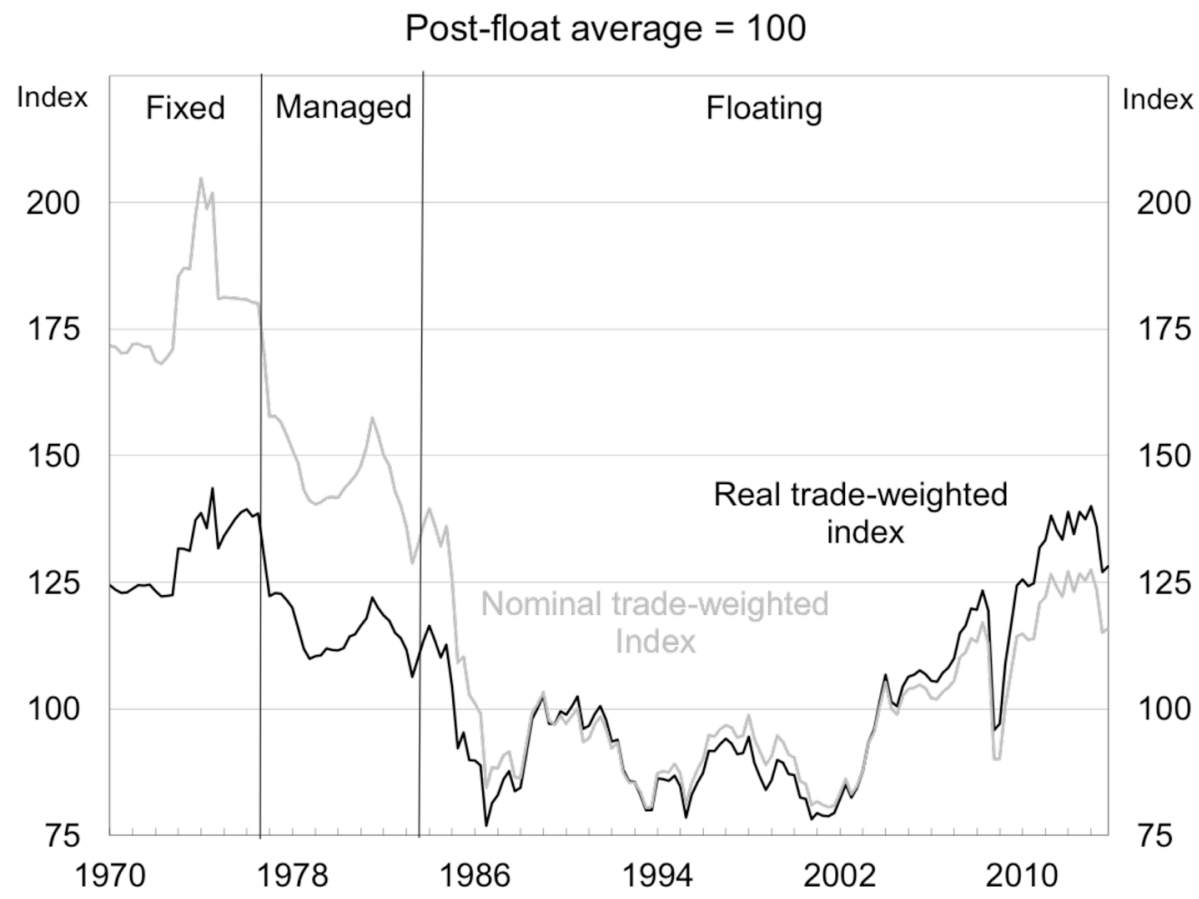

Figure 11.4 Australian Nominal and Real Exchange Rates

Sources: Australian Bureau of Statistics (ABS); The Reserve Bank of Australia (RBA);

Thomson Reuters; WM/Reuters Service at <http://www.wmcompany.com/wmr/index.htm>.

In 1976, speculators forced a further large, discrete devaluation of the currency, leading to the adoption of a crawling peg (Laker 1988). The crawling peg was intended to prevent the build-up of appreciation or depreciation pressures (followed by large discrete adjustments). The value was to be set daily by joint decision of the RBA, Treasury and the Department of Prime Minister and Cabinet. While day-to-day changes in the value of the Australian dollar were initially small and infrequent, they became larger and more frequent over time. For example, in 1977 the value of the Trade Weighted Index (TWI) peg was adjusted on just 46 trading days, whereas in 1983 the TWI was adjusted on 121 trading days (prior to the eventual float of the currency on 12 December). Nevertheless, the magnitude of daily movements was still small compared with 
movements in floating currencies. Daily changes in the Australian dollar TWI rarely exceeded 0.2 per cent, whereas for the major currencies daily movements of more than 1 per cent were not uncommon (Laker 1988).

The large, discrete revaluations of the Australian dollar over the preceding few years - and then the introduction of an increasingly flexible peg to the TWI-meant the Australian dollar's bilateral exchange rate with the US dollar had become more variable. At the same time, firms were also increasing their use of foreign funding sources. As a result, firms were exposed to a greater degree of foreign currency risk than previously, providing them with stronger incentives to manage their foreign currency exposure actively.

In response, the private sector developed an unofficial foreign currency hedging market in an effort to supplement the relatively limited forward cover that was provided at the time by the RBA. ${ }^{13}$ This market was an onshore nondeliverable forward (NDF) market: as the contracts were settled in Australian dollars, they did not violate the existing exchange controls. The onshore NDF market is now recognised as having been an important precursor to modernday hedging markets, which have developed to play a crucial role in insulating Australian entities from foreign currency risk under the floating exchange rate regime. ${ }^{14}$

\section{The 1980s}

Although increased innovation and integration in financial markets were a natural consequence of deregulation, they also made Australia's system of exchange controls increasingly ineffective. For example, the NDF market provided a means by which participants could speculate on the exchange rate without the need for large upfront payments, while the gradual freeing up of restrictions on deposit rates (which ultimately included the removal of all ceilings on deposit rates by 1980) made it easier for banks to attract foreign funds (Battellino 2007).

The decreasing effectiveness of Australia's capital controls placed additional pressure on Australia's crawling peg. Large capital flows often occurred in anticipation of future change in the exchange rate, or in response to the RBA's attempts to tighten monetary policy. Under the managed exchange rate regime, these flows affected the money supply and contributed both to large misses

13 The RBA only provided forward cover for trade-related transactions, not for capital transactions. Further, from May 1974 this cover had to be obtained within seven days of the transaction. This was known as the 'seven-day rule'. It was introduced to prevent participants from taking out forward cover just before an expected revaluation (Manuell 1986:177; Debelle and Plumb 2006).

14 For more information on foreign currency hedging in Australia, see Becker and Fabbro (2006) and Rush et al. (2013). 
of the monetary targets in the early 1980s and to volatility in short and longterm interest rates. ${ }^{15}$ Consequently, by the late 1970s and early 1980s, Australia's relative exchange rate stability was being achieved at the cost of volatility in domestic financial conditions (Debelle and Plumb 2006).

While some measures were introduced in an attempt to counteract these capital flows, they ultimately proved ineffective. ${ }^{16}$ On 9 December 1983, faced with the prospect of further large capital inflows, the authorities suspended banks' foreign currency trading to allow time to decide on a course of action. The decision was made to float the Australian dollar-effective from 12 December 1983. While some brief consideration appears to have been given to the alternative option of strengthening capital controls, such controls were considered costly, ineffective and inefficient (Laker 1988).

Although the decision to float the dollar and to liberalise the capital account was taken over the course of just one day, there had been growing acceptanceat least among some policymakers - of the potential merits of a more flexible exchange rate regime for some years. For example, in 1981 the Campbell Committee inquiry into the Australian financial system had recommended moving to a floating exchange rate regime, noting that exchange controls were costly and inefficient and were unlikely to be effective in regulating short-term capital flows (Laker 1988). Most capital controls were removed at the same time as the float, because they existed largely for the purpose of maintaining the fixed exchange rate. One key exception was a ban on foreign government and central bank purchases of Australian interest-bearing assets, which was maintained in an attempt to ensure that the Australian dollar would not become a reserve currency (Phillips 1985).

Deregulation of the banking sector was not complete at the time of the float. While interest rate ceilings had been removed for all deposits, ceilings on lending rates had been removed only for loans exceeding $\mathrm{A} \$ 100000$. Moreover, the banking sector also remained subject to a number of balance sheet restrictions, with these restrictions - as well as the interest rate ceilings on small loansremaining in place until the mid to late 1980 s. $^{17}$

15 The large misses of the monetary targets occurred despite introduction of the 'tender' system for primary issuance of government securities, which gave authorities more control over domestic liquidity. For more details, see Grenville (1991).

16 In particular, a number of measures were introduced to prevent participants from speculating on the next day's Australian dollar/US dollar mid-rate based on movements in major currencies during Australia's trading day. These included announcing the mid-rate in the afternoon, rather than in the morning, and occasionally making unexpected changes to the TWI peg (Debelle and Plumb 2006).

17 For a timeline of the changes to bank regulations, see Battellino and McMillan (1989). 
The immediate effects of floating the Australian dollar and liberalising the capital account were largely as expected. In particular, capital outflows increased substantially as the relatively restrictive controls on overseas investment by Australian residents were removed (Figure 11.5). Capital inflows increased by even more, however, and net capital inflows settled at a level that was somewhat higher than they had been before the capital account was liberalised (Battellino and Plumb 2011).

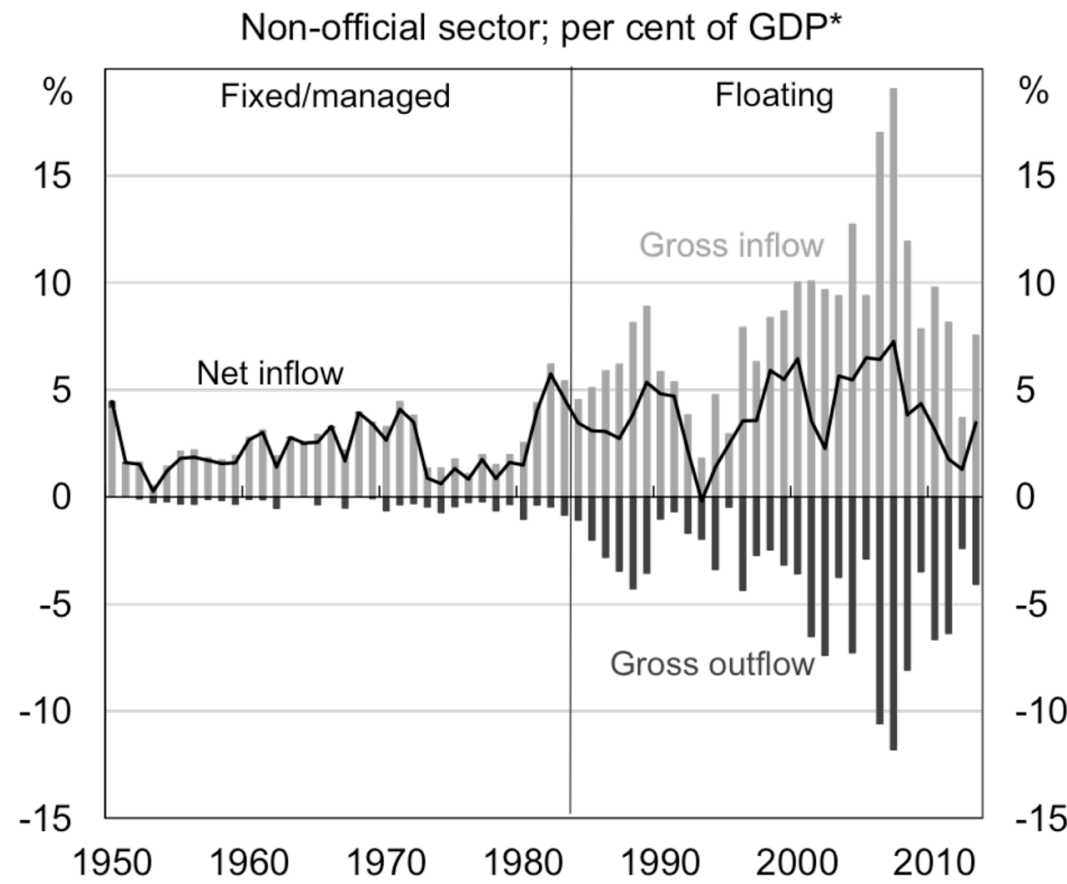

Figure 11.5 Australian Gross and Net Capital Flows

Sources: Australian Bureau of Statistics (ABS); The Reserve Bank of Australia (RBA);

Note: Excludes financial derivatives where data are available.

Meanwhile, the exchange rate naturally became more volatile after the float, interest rates became more stable and authorities were better able to control domestic financial conditions (Figure 11.6). This was reinforced by the adoption of an inflation target in the early 1990s, which was the culmination of an extended search for a credible nominal anchor and framework for monetary policy (Stevens et al. 2010). 
Absolute monthly change; 6-month rolling average

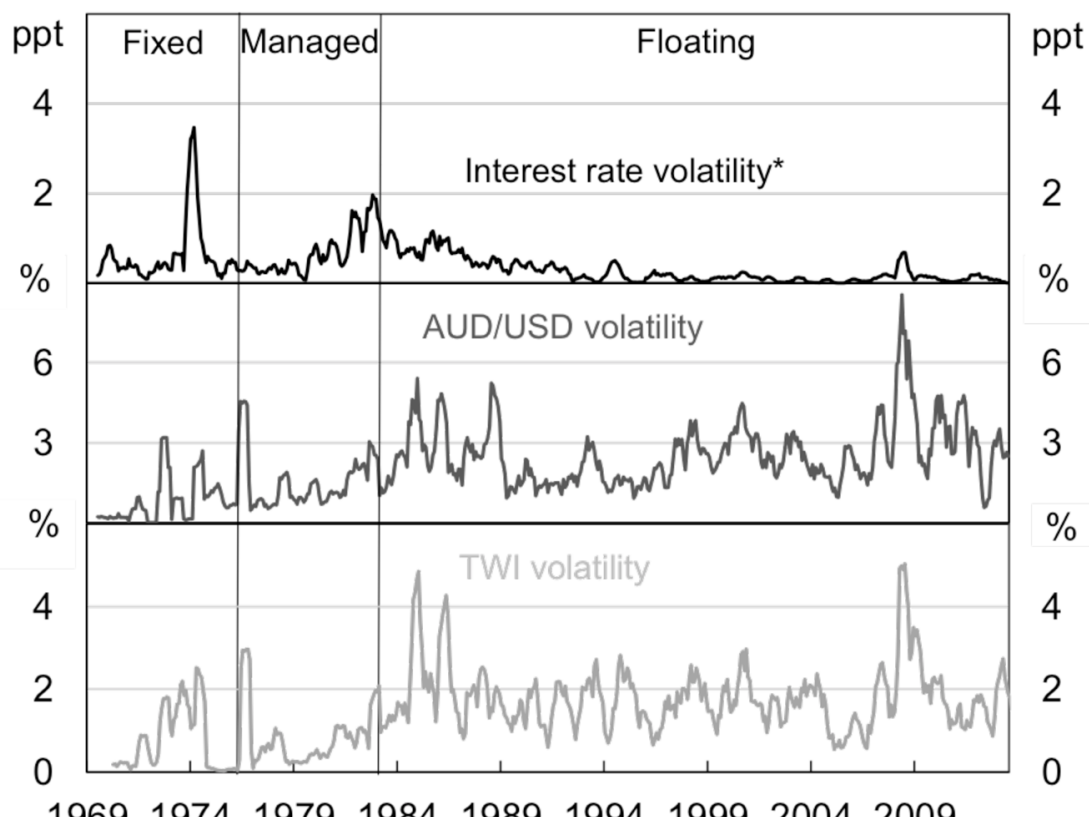

196919741979198419891994199920042009

Figure 11.6 Australian Interest Rate and Exchange Rate Volatility

* 90-day bank bill

Sources: AFMA at <http://www.afma.com.au/home.html>; Bloomberg; Global Financial Data; Thomson Reuters.

Although the float itself was intended to be relatively 'clean', the RBA intervened frequently to influence the foreign exchange market throughout most of the 1980s. The RBA's intervention transactions during this so-called 'testing and smoothing' period tended to be small in size- but relatively frequentand were designed both to increase the RBA's understanding of how the market operated and to dampen episodes of substantial volatility (Becker and Sinclair 2004; Newman et al. 2011). The focus on reducing volatility during these early years was motivated in large part by the fact that foreign exchange market participants still had relatively limited experience of managing their foreign currency exposure; however, as the foreign exchange market developed-and, in particular, as the supply of foreign exchange derivatives for hedging purposes increased - the RBA became less concerned about market participants' ability to hedge their exchange rate risk. As a consequence, intervention transactions became less frequent, but more targeted towards addressing episodes of market dysfunction. There were also some episodes where intervention was designed to affect the level of the exchange rate, rather than market dysfunction per se, but these were rare. 


\section{Developments since the float}

The decision to introduce a floating exchange rate is now widely recognised as having brought substantial benefit to the Australian economy (Beaumont and Cui 2007; Lowe 2013; Stevens 2013). In addition to the advantages associated with monetary policy independence, exchange rate flexibility has played a crucial role in buffering the economy from external shocks, in particulargiven Australia's status as a small, open commodity exporter-from terms-oftrade shocks. The exchange rate's role as a buffer was also exemplified during the Asian financial crisis in 1997-98, the tech boom and bust in the early 2000s, and again during the GFC in 2008-09. Sharp depreciations of the Australian dollar during each of these episodes served to offset part of the contractionary effects of these crises.

Nevertheless, there were challenges associated with Australia's adoption of a floating exchange rate, particularly in the early stages of the regime. Most notably, deficiencies in the prudential supervision framework and an underdeveloped foreign exchange hedging market meant that the transition was not smooth; however, both of these elements - which are now recognised as being crucial for minimising the financial instability risks that can be associated with a floating exchange rate and open capital account - have developed over time. In part, this has occurred in response to the incentives created by the floating exchange rate regime itself.

\section{Banking supervision}

At the time of the float, Australian banks and regulators were relatively inexperienced at assessing and pricing risk, notwithstanding some of the earlier steps taken towards financial deregulation in the 1970s. This reflected the fact that banking sector regulations had served to ration credit, so banks were accustomed to - and able to profit from - lending only to the most creditworthy borrowers. Consequently, they had not developed the ability to assess and price risk for less credit-worthy borrowers (Thompson 1991; Lowe 2013).

When these regulations were removed, banks attempted to expand their market share by offering credit to higher-risk borrowers. This competition for market share intensified with the entry of foreign banks in the mid 1980s and was, at least in part, funded by increased capital inflows associated with the removal of capital controls. The combination of pent-up demand for credit, relatively underdeveloped risk-assessment frameworks (both for banks and for prudential supervisors), freer access to overseas capital and increased competition led to a boom in credit, and then to a bubble, and eventual bust, in commercial property prices in the late 1980s and large losses for banks (Figure 11.7). This episode led 
to an increase in the pace of reform to risk-management practices for banks and regulators and, later, a broader overhaul of the regulatory framework (Gizycki and Lowe 2000).

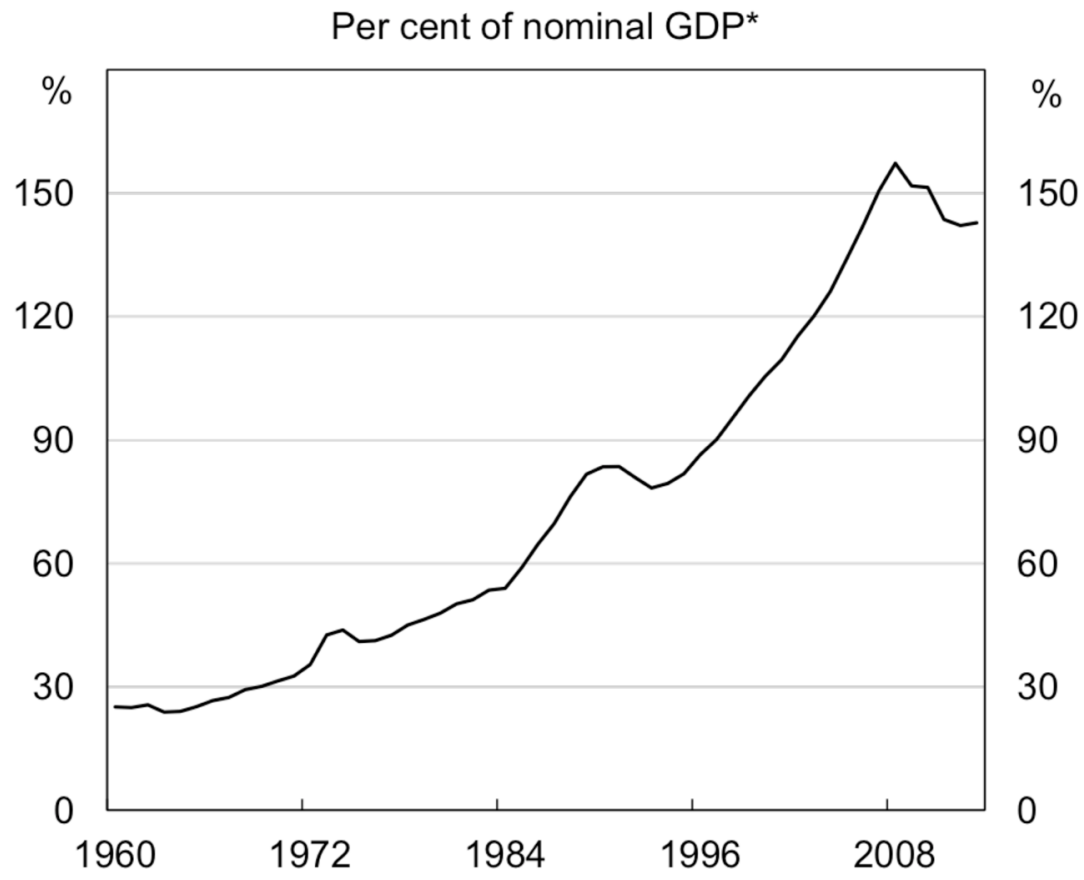

\section{Figure 11.7 Australian Credit}

Sources: Australian Bureau of Statistics (ABS); The Reserve Bank of Australia (RBA); Australian Prudential Regulation Authority (APRA) at <http://www.apra.gov.au/Pages/default.aspx $>$.

Note: Not adjusted for breaks.

\section{Development of hedging markets}

Market participants had developed a relatively small foreign exchange derivatives market before the float. Yet the float proved to be the catalyst for further development in Australia's (non-deliverable) hedging and (deliverable) foreign exchange markets, with these markets doubling and tripling in size, respectively, within a year (Phillips 1984a) (Figure 11.8). 
Daily average; per cent of annual GDP*

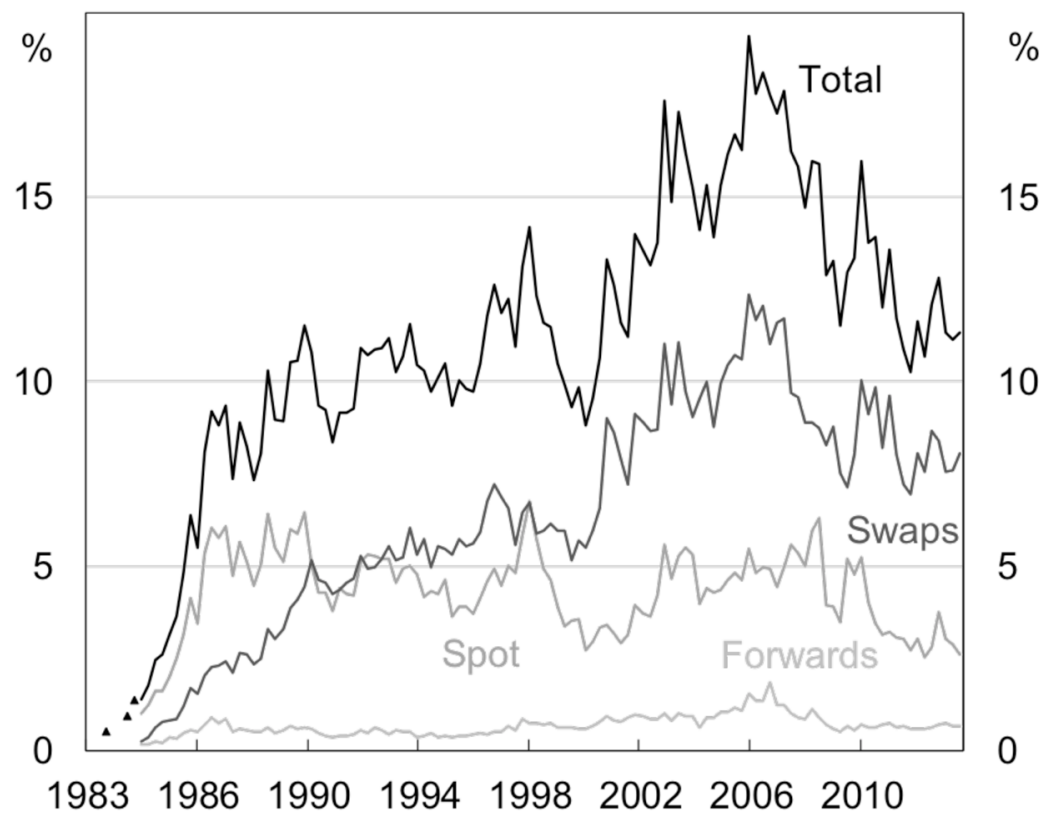

Figure 11.8 Foreign Exchange Turnover in the Australian Market Sources: Phillips (1984a); The Reserve Bank of Australia (RBA).

Note: Excludes the non-deliverable 'hedge' market, which existed until the late 1980s.

Nevertheless, it took time for hedging practices to develop. While some entities had gained experience in managing their foreign currency exposure during the pre-float period, others were not sufficiently aware of the risks of such exposure in the early stages of the floating exchange rate regime. For example, in the mid 1980s a number of borrowers took out loans denominated in Swiss francs, without being adequately prepared for the potential exchange rate risk associated with this practice. When the Australian dollar depreciated sharply between 1985 and 1986, many were unprepared for the higher Australian dollar payments required to service the loans. While the scale of the borrowing and the associated losses were relatively small, the episode received a large amount of publicity. The high-profile nature of the episode, together with agents' growing experience with a relatively volatile floating exchange rate, may help to explain the relatively high level of hedging in the Australian economy today (Becker and Fabbro 2006; Battellino and Plumb 2011).

Finally, the market also needed to develop a deep and diverse pool of participants. In particular, the ability of Australian entities to hedge their foreign currency risk ultimately depends on foreigners being willing to hold Australian 
dollar exposure. ${ }^{18}$ This demand for Australian dollar exposure depends on both the return and the perceived risk associated with the investment. Over time, the latter has been closely linked to investors' perceptions about the credibility of Australia's economic policy framework and institutions.

\section{China's Financial System Reforms}

Unlike Australia in the early 1980s, China's financial system reforms have occurred as part of a gradual, closely managed transition from a centrally planned economy towards a market-oriented economy. Prior to the period of 'reform and opening' initiated in December 1978, interest rates on loans and deposits were set directly by the Central Government; the interbank market, stock markets and bond markets did not exist; the renminbi was largely unconvertible for current and capital account transactions; and foreign investment was negligible. The decision to reform the financial system occurred at an early stage, and was consistent with a broader retreat from central planning towards a hybrid economic model characterised by a growing role for the market economy but continued high levels of government intervention.

Ambitious reforms to build a modern financial system and reduce the role of the state in the economy in the 1990s accelerated China's move towards deregulation; but rising banking sector fragility and the non-performing loan (NPL) crisis of the late 1990s - combined with the 1997-98 Asian financial crisis - highlighted the potential risks of moving quickly on financial reform, contributing to a very gradual pace of reform in the 2000 s.

\section{The expanding financial system}

Initially, economic reforms focused on reducing price controls and creating market incentives in agriculture, and reducing barriers to entry in industries previously controlled by state-owned enterprises (SOEs). This resulted in rapid growth in productivity and output that was accompanied by an expansion of the financial system.

18 While there are some natural counterparties who wish to hedge Australian dollar exposures into foreign currencies, such as Kangaroo-bond issuers, these are not sufficient to meet the demand for the hedging of foreign currency exposures into Australian dollars. Consequently, foreign investors have tended to take a net long position in the Australian dollar (McCauley 2006). 


\section{Banking system and interest rate regulation in the 1980s}

Banking deregulation in China followed a distinctly different path to that in Australia, in part because of the dominant role of SOEs and state-owned banks in the Chinese economy. In the pre-reform era, household savings were low and banks acted effectively as conduits for trade credit and working capital to SOEs, within limits set by a centrally determined credit plan. At the outset of reform, financial services were provided by three state-owned banks and a network of rural credit cooperatives (RCCs) that provided banking services in rural areas. Through the mid and late 1980s, the authorities approved the creation of numerous new national and regional bank and non-bank financial institutions, regulated by the $\mathrm{PBC}$, which was designated as the central bank in 1983. ${ }^{19}$ By the mid 1980s, a large number of non-bank financial intermediaries, including urban credit cooperatives and trust and investment companies, had emerged to supplement the SOE-oriented lending activities of banks and to meet the funding needs of the growing non-state sector (Lardy 1998:61-76).

At the start of reforms, the schedule of interest rates for deposits and loans of various tenors and types was set centrally by the Government. As the banking system expanded, however, the authorities began to experiment with increased interest rate flexibility. In 1983, the PBC was authorised by the State Council (China's cabinet) to vary interest rates by 20 per cent on either side of centrally determined benchmark rates. ${ }^{20}$ Yet policymakers were initially reluctant to increase the floating range of interest rates, fearing it would harm the profitability of enterprises (Yi 2009). ${ }^{21}$

The authorities also experimented with floating deposit rates for RCCs, and trust and investment companies, but these pilot reforms were aborted when the resulting competition for deposits (particularly by the more poorly performing financial institutions) led to substantial movements of deposits across institutions and violations of interest rate ceilings on other products (PBC 2005). In 1987, the PBC permitted the large banks to increase lending rates for working capital loans by up to 20 per cent over the benchmark rate. In 1990 this flexibility was extended to lending rates for commercial banks and urban credit cooperatives, but problems that had been experienced in pilot efforts to float deposit rates led the authorities, in the same year, to prohibit increases in deposit rates above the benchmark for all financial institutions (PBC 2005).

19 The PBC coordinated with the State Planning Commission to develop the national credit plan. It was legally confirmed as the central bank in 1995 .

20 This authorisation was given in State Council Document No. 100 (1983).

21 For this reason, the upward flexibility of lending rates was reduced to 10 per cent in 1996 (Yi 2009). 


\section{Capital controls and the exchange rate in the 1980s}

Prior to economic reform, the Chinese Government had imposed a centralised foreign exchange system whereby detailed plans had to be submitted to the authorities for approval in advance of all trade-related or foreign investmentrelated foreign exchange transactions, foreign investment projects or external borrowing (Prasad and Wei 2005). All foreign exchange earnings had to be sold to the Government. This restrictive foreign exchange system had a parallel in restrictions on foreign trade: in the early years of reform, exports and imports were controlled by a complicated schedule of trading rights, import licences, quotas and tariffs (Lardy 2002: ch. 2).

The growth of the domestic financial system in the 1980s coincided with increasing openness to world trade, a dismantling of the pre-reform system of centrally planned exports and imports, and increased international flows of capital. To support inward direct investment, numerous 'special economic zones' featuring tax and other incentives to attract foreign investment were established. Regulations announced in 1980 retained centralised foreign exchange management (that is, requiring approval for individual current and capital account transactions), but resident entities and foreigners were allowed to retain or trade a portion of their foreign exchange.

The increased availability of foreign exchange onshore led to the creation of a market-based foreign exchange market (sanctioned by the Government) alongside the official market. A dual exchange rate system emerged, with only around 20 per cent of foreign exchange traded at the official rate (Yi 2008). From the mid to late 1980s, the official rate was devalued several times to bring it more in line with the market-determined rate, but the dual system prevailed until 1994.

\section{Growth of financial markets and banking sector fragility in the 1990s}

The period beginning in the mid 1990s and ending in the early 2000s saw an expansion of China's financial market infrastructure, but also risks to financial stability. Seeking to diversify funding for the corporate sector, the Government opened the Shanghai and Shenzhen stock exchanges in 1990 and 1991, respectively, and subsequently allowed the creation of numerous regional exchanges. These exchanges became a platform for various financial instruments including shares, government bonds and corporate bonds. Local currency bond repurchase agreements (repos) were first introduced in 1991 on a number of securities trading platforms, and in 1993 on the Shanghai Stock Exchange. 
The development of capital market infrastructure centred on the stock exchanges resulted in leakages of bank funding, via securities companies and institutional investors, into the stock market. This aroused concern among policymakers about systemic risks stemming from rapid growth in asset prices. In response, in 1997-98 the Government created separate regulatory frameworks for the banking, trust, securities and insurance sectors, eliminated smaller securities markets and required all banks to migrate their business from the exchange markets to the interbank market, which had been expanding since the mid 1980s (Zheng 2007:52; Tan 2007:223-4). Between 1997 and 1999 interbank markets for bonds and repos were established, with floating interest rates for government bonds and policy financial bonds. ${ }^{22}$

Although the size of financial markets increased during the 1990s, they remained small compared with the formal banking system, whose fragility was underscored by the NPL crisis of the late 1990s. The crisis had its origins in the rising leverage of the SOEs. Growing competition from the private sector, and declining state support, led to more bank borrowing by unprofitable SOEs and a sharp rise in inter-enterprise liabilities - or 'triangular debt' — as firms incurred debts (often in the form of unpaid bills) to other firms. Some observers estimate that more than half of China's SOEs were insolvent by the mid 1990s (Lardy 1998:175).

Despite efforts to reform the SOEs through privatisation initiatives and to improve the asset-liability management of the banks (including imposing a 75 per cent maximum loan-to-deposit ratio), by 1997-98 the largest four banks' NPLs had risen to between one-quarter and one-third of total assets (Bonin and Huang 2001). Although China's strong capital controls allowed it to weather the 1997-98 Asian financial crisis, the concurrent NPL crisis heightened policymakers' concerns about domestic financial fragility. The Government responded swiftly, recapitalising the state-owned banks, introducing debtfor-equity swaps and creating four asset-management companies to purchase banks' NPLs at face value and begin the process of their disposal (PBC 2000:318). Subsequently, NPLs moderated steadily, but the fragility in the banking system that surfaced in the late 1990s contributed to subsequent gradualism in domestic financial reform. 
Steps towards interest rate deregulation in the late 1990s early 2000s

The 1990s saw incremental progress in deregulating bank lending and deposit rates. In 1993, the State Council issued a decision on financial system reforms that incorporated a strategy for interest rate liberalisation (PBC 2003:14). Following the deregulation of interbank lending and repo rates in the mid to late 1990s, the PBC resumed efforts to increase the flexibility of bank lending rates. The PBC's objective was to encourage banks to lend to small and medium enterprises, which tended to receive fewer loans than larger firms that were seen to be more credit-worthy (Yi 2009). In the late 1990s and early 2000s, interest rate ceilings for bank loans to small and medium-sized enterprises and foreign currency loans, and RCC lending rates were granted further flexibility (PBC 1999:22; 2000:26). In October 2004, ceilings on almost all lending rates were abolished while the floor was retained at 0.9 times the benchmark.

Efforts to reform deposit rates also resumed towards the end of the decade. In 1999 the $\mathrm{PBC}$ took tentative steps towards liberalising wholesale deposit rates by allowing banks flexibility to negotiate contract interest rates for largescale commercial deposits with insurance companies (PBC 2003:15). Similar to the experience of the 1980s, broader reforms to deposit rates were delayed by concerns that upward flexibility would lead to unhealthy competition among banks that would diminish their margins. A small-scale trial to reduce ceilings on RCCs' deposit rates in 2002 failed to achieve the expected results, leading once again to such efforts being postponed (Guo 2013). But there was increasing recognition that the floors on deposit rates were redundant, and by October 2004 the floor on interest rates had been abolished for all deposits (Yi 2009). The 2004 reforms marked the start of a policy to manage only the floors of lending rates and the ceilings of deposit rates, effectively guaranteeing a minimum net interest margin for the banks.

\section{The currency regime and capital controls in the 1990s}

Moves to increase the flexibility of interest rates occurred alongside changes to exchange rate policy. In January 1994 the official and market-based exchange rates were unified at the prevailing market rate. This resulted in a large official devaluation of the renminbi (Figure 11.9). The exchange rate was initially allowed to follow a managed float, which resulted in gradual appreciation, but the authorities reimposed a peg to the US dollar during the Asian financial crisis, with this peg remaining in place until 2005. 


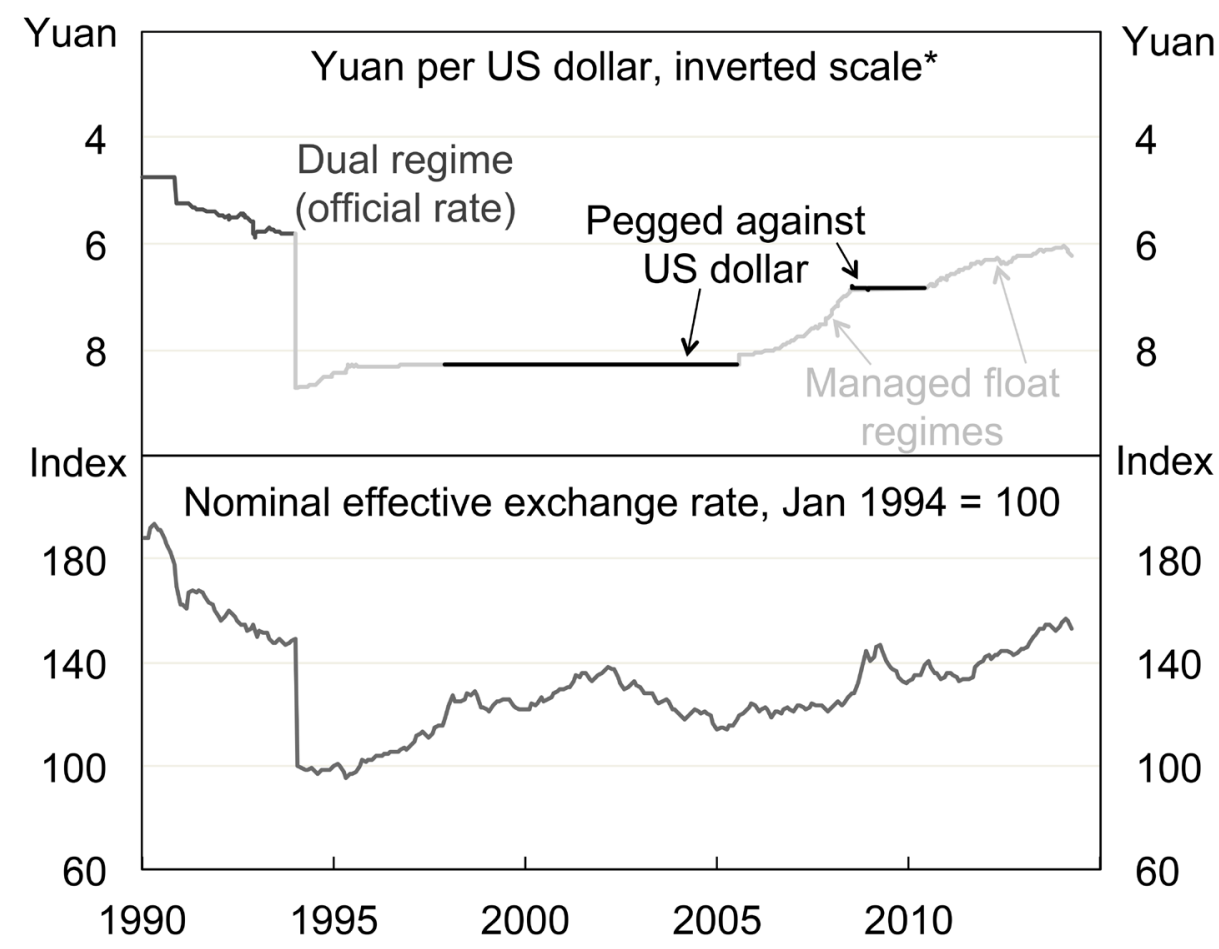

Figure 11.9 Chinese Renminbi

* Onshore exchange rates

Sources: Bank of International Settlement (BIS); Bloomberg; The Reserve Bank of Australia (RBA).

The 1994 exchange rate reform resulted in changes in the implementation of China's foreign exchange controls. The interbank China Foreign Exchange Trade System (CFETS) was established, initially with the PBC as the sole market maker and counterparty. Most enterprises were required to sell all foreign exchange earnings above certain limits to authorised banks, which would in turn convert these funds to renminbi on the CFETS. Importers seeking to purchase foreign exchange for trade settlement were required to submit import contracts and other documentation to authorised banks.

In 1996, China formally achieved convertibility on the current account, defined as trade in goods and services, net income from foreign investments and labour remittances. While current account transactions still required the submission of supporting documents and most foreign exchange earnings had to be sold to the banks, these transactions no longer required formal approval from the authorities. Capital account transactions, however, remained tightly 
controlled: all foreign exchange transactions affecting the foreign assets or liabilities of domestic residents either required official approval or were explicitly prohibited (Le 2007:114).

Similar to the Australian experience, in China, inward direct investment continued to be encouraged, and expanded significantly from the mid 1990s, albeit remaining subject to review by relevant authorities and subject to the Government's industrial policies. In contrast, portfolio flows such as transactions in capital market securities or money market instruments were generally prohibited without prior approval (Prasad and Wei 2005).

While the period between the early 1990s and the early 2000s saw modest changes in capital controls, it is likely that China's experience during the Asian financial crisis increased the Government's level of comfort with the prevailing arrangements (Yu 2013). Despite large currency depreciations among China's trading partners during the crisis, which led to a loss of competitiveness for Chinese exporters, policymakers resisted the temptation to engage in competitive devaluations and instead decided to peg the renminbi to the US dollar and accept export losses (Hu 2010). While China's trade performance during the crisis was poor, the strong capital controls in place provided substantial insulation from speculative capital flows. Following current account convertibility in 1996, policymakers initially planned to achieve capital account convertibility within five to 10 years (Huang et al. 2013:109), but the Asian financial crisis, and rising banking sector stress in the late 1990s, contributed to these plans being postponed.

\section{China's evolving financial reform agenda}

In the past decade, the overall framework of tight internal financial regulation, strong controls on portfolio capital flows and a steadily appreciating currency has remained in place, although there have been a number of significant changes. First, the regulatory framework has been strengthened, including through the creation of a separate banking regulator in 2003. Second, interest rates and the exchange rate have been given increased flexibility. Third, the emphasis of monetary policy has shifted. The PBC continues to guide individual banks' credit extension to priority sectors ('window guidance') and maintains informal loan quotas, but it has phased out mandatory credit ceilings, and has made more use of interest rate changes, required reserve ratio adjustments and open market operations. Fourth, further restrictions on capital flows have been removed, in particular those relating to inbound FDI in manufacturing. While control of portfolio flows has remained tight, since the late 2000s efforts by the authorities to promote the internationalisation of China's currency have seen growth in offshore renminbi deposits and an increase in avenues for cross-border flows. 


\section{Banking sector deregulation}

According to Huang et al. (2013:97), between 1996 and 2007 around 120 types of interest rates underwent reform. In general, the approach to interest rate liberalisation followed the sequencing principles of 'foreign currency interest rates before local currency interest rates', 'loans before deposits', 'longterm wholesale interest rates before short-term retail interest rates' and 'rural areas before urban areas' (PBC 2000:26; 2005). In 2012, the PBC reduced the floor on lending rates and increased the flexibility of deposit rates slightly. In 2013 it abolished all restrictions on lending rates (except for rates on individual mortgages). ${ }^{23}$

Although lending rates are now largely liberalised, authorities have been reluctant to remove ceilings on regulated deposit rates. In late 2013, as a preliminary step towards deposit rate liberalisation, the PBC announced that banks would be given the flexibility to set negotiable rates on interbank CDs. In March 2014, the PBC's governor stated that deposit rates could be liberalised within one to two years (PBC 2014).

While policymakers have remained cautious about formally deregulating deposit rates, a significant de facto liberalisation of deposit rates has occurred in recent years. In response to the GFC of 2008-09, the authorities initiated a large-scale loosening of credit conditions to support growth (Figure 11.10). With banks restricted in lending by loan-to-deposit ratios and local governments restricted from borrowing directly on capital markets, the policy easing led to a rise in borrowing from corporate entities established by local governments, and significant intermediation of funds through NBFIs - particularly trust companies - working in cooperation with commercial banks. Banks were able to fund loans, off-balance sheet, to local governments, property developers and manufacturing firms by issuing 'wealth management products' - effectively term deposits with interest rates that were much higher than regulated deposit ceilings.

23 By this stage the floor on lending rates was not effectively binding: only 37 per cent of loans were extended at rates below or at the benchmark as of June 2013. 
Annual flows; per cent of GDP

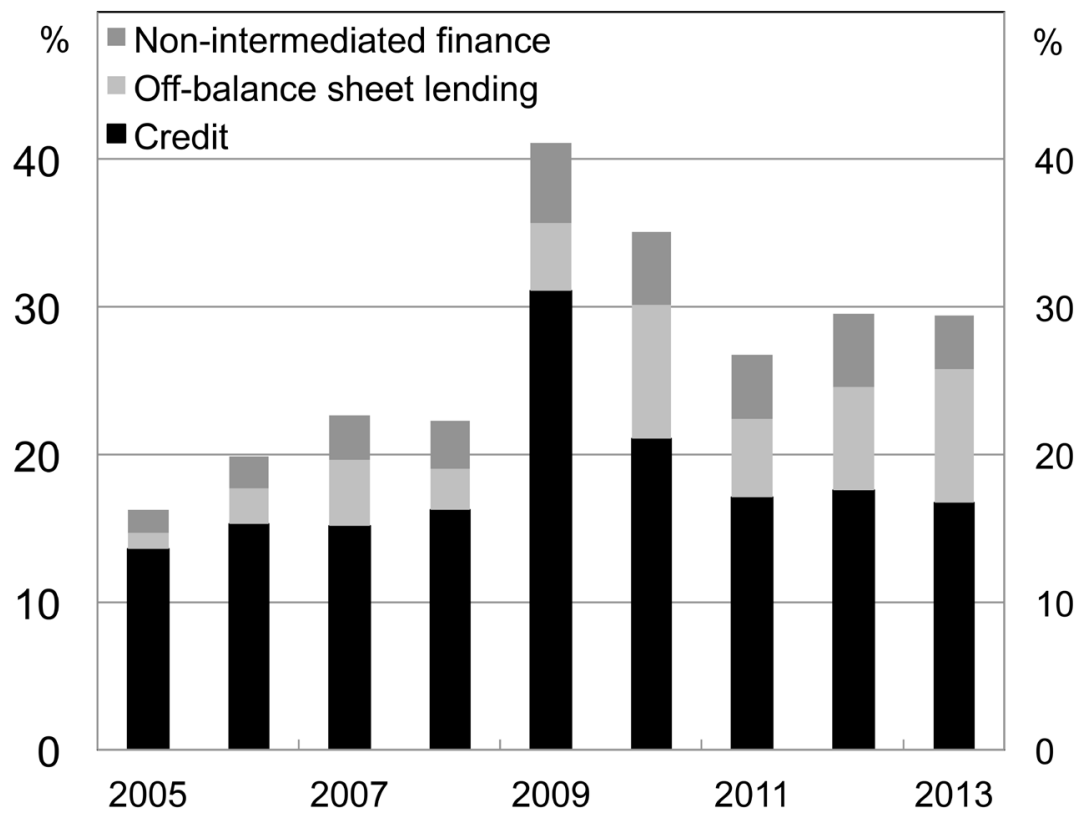

Figure 11.10 Chinese Total Social Financing

Sources: CEIC data at <http://dev.ceicdata.securities.com/about_ceic.html>; The Reserve Bank of Australia (RBA).

\section{Capital controls}

Since the early 2000s, capital controls have continued to be eased very gradually, although FDI in the services sectors (including financial services) continues to be limited and portfolio flows remain to a large extent forbidden. As a share of GDP, both gross and net flows have not increased dramatically compared with the 1990s, although they remain well above the level of the 1980s (Figure 11.11). Restrictions on foreign exchange purchases for foreign currency loans, foreign debts and pre-approved strategic foreign projects were removed in the early 2000s, and in 2002 a Qualified Foreign Institutional Investor (QFII) program allowed approved foreign investors to invest foreign currency in domestic shares. This scheme has been expanded and approved QFIIs can now invest foreign currency in equities, bonds, securities, funds, stock index futures and other financial instruments permitted by the securities regulator. The renminbi QFII (RQFII) scheme, initiated in late 2011, allows selected foreign financial institutions to invest renminbi obtained offshore in approved onshore assets. The Qualified Domestic Institutional Investor (QDII) scheme, initiated in 2006, allows authorised domestic institutions to invest funds raised onshore in selected offshore investments. 
Non-reserve flows; per cent of GDP

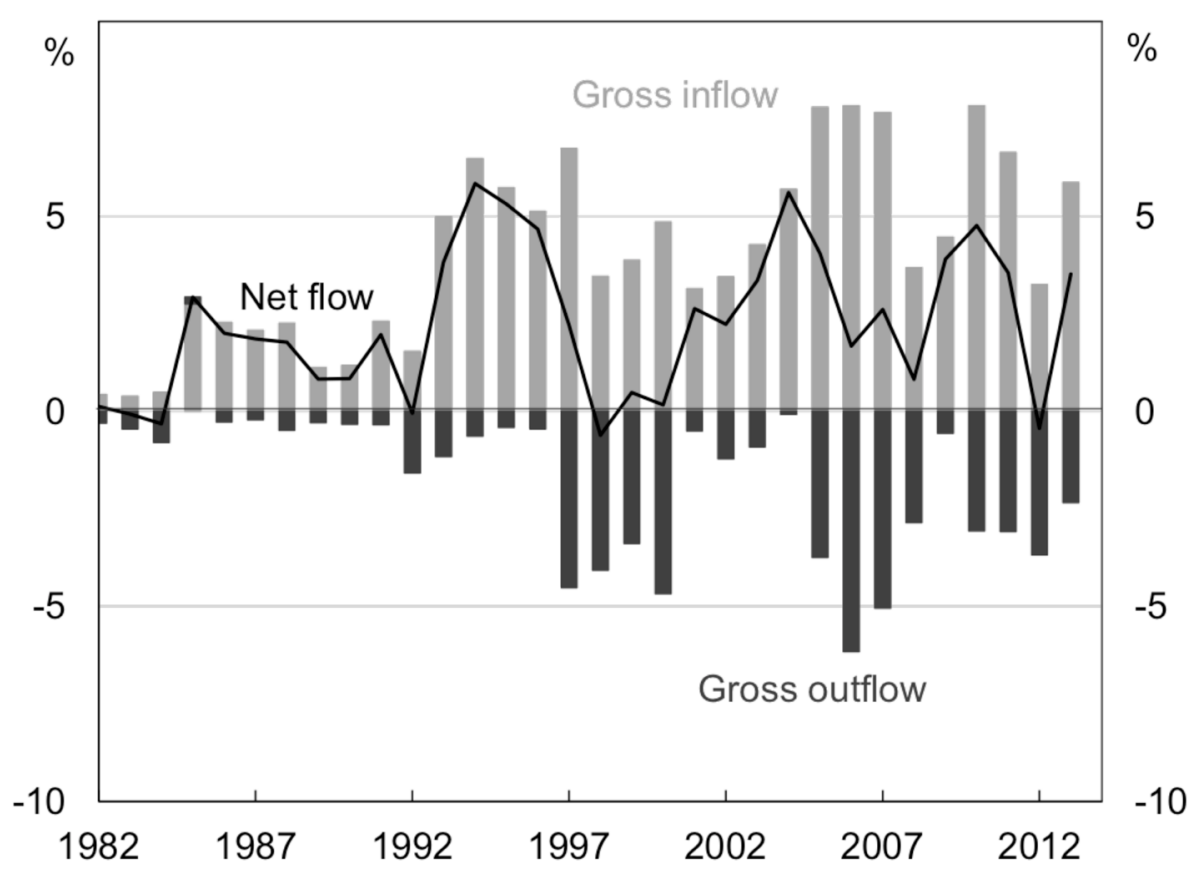

Figure 11.11 Chinese Gross and Net Capital Flows

Sources:CEIC data at <http://dev.ceicdata.securities.com/about_ceic.html>; The Reserve Bank of Australia (RBA).

Notwithstanding the expansion of these programs, FDI has continued to be the largest contributor to flows registered on the Chinese capital account in recent years, along with 'other' flows that appear to be mostly related to banks' and firms' short-term internal financing and trade credit (Figure 11.12). In 2013, total FDI (that is, the sum of inward and outward FDI) was worth approximately US $\$ 330$ billion, or roughly 3.5 per cent of GDP. Cross-border portfolio investment schemes are relatively modest by comparison. PBC data indicate that the foreign liabilities of banks and other deposit-taking institutions (domestic-owned and foreign-owned) in China totalled approximately US $\$ 360$ billion at the end of February 2013 - much greater than the roughly US\$76 billion of net foreign investment accounted for by the QFII and RQFII schemes. Even total foreign liabilities, however, represent only 1.4 per cent of the total liabilities of the banking system, implying that the Chinese banking system's current exposure to international markets is small. 


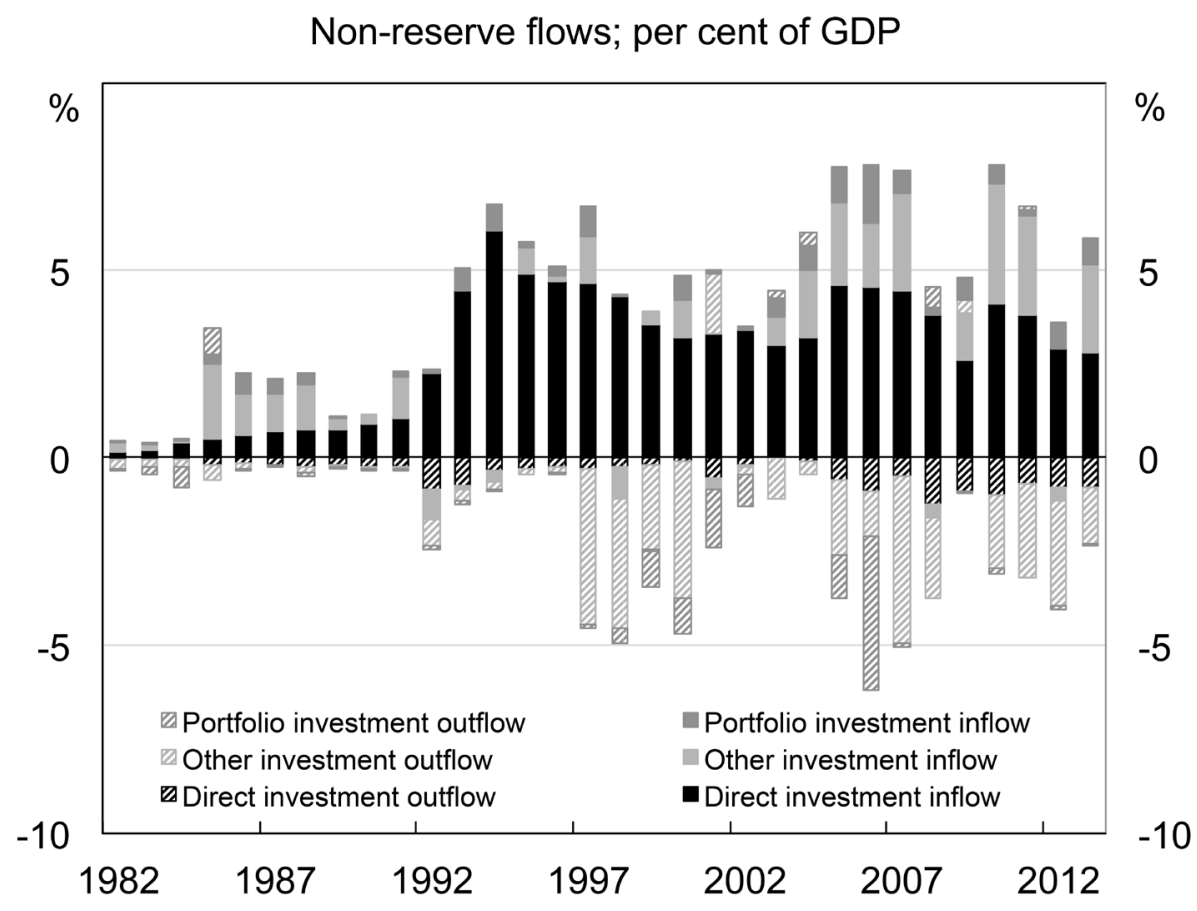

Figure 11.12 Chinese Gross Capital Flows

Sources: CEIC data at <http://dev.ceicdata.securities.com/about_ceic.html>; The Reserve Bank of Australia (RBA)

\section{The exchange rate}

Following its 're-pegging' during the Asian financial crisis, the US dollar/ renminbi exchange rate was effectively fixed until July 2005, when the PBC announced that it would manage the renminbi in a 0.3 per cent band (later 0.5 per cent) against an undisclosed basket of currencies. This arrangement marked the beginning of a period of steady appreciation of the renminbi against the US dollar, aside from a two-year pause beginning in mid 2008 associated with the GFC. Appreciation pressures on the renminbi and the steady inflow of foreign currency due to the trade surplus (and, to an increasing extent, capital account inflows) following China's accession to the World Trade Organisation (WTO) in 2001 meant that the $\mathrm{PBC}$ needed to intervene in the spot foreign exchange market to maintain the trading band. ${ }^{24}$ This has contributed to a quadrupling of China's foreign exchange reserves to US\$3.8 trillion between 2005 and 2013.

24 The need to sterilise the domestic liquidity impact of these purchases of US dollars/sales of renminbi led to more intensive use of required reserve ratio adjustments in the second half of the 2000s (Ma et al. 2011). 
Since mid 2005, the renminbi has appreciated by 33 per cent against the US dollar and by 42 per cent in real effective terms. In April 2012, the PBC widened the renminbi's daily trading band against the US dollar from $+/-0.5$ per cent to $+/-1$ per cent around its daily central parity rate ('fixing rate'), set by the PBC (via the CFETS) each trading day as part of its management of the renminbi against a basket of currencies. ${ }^{25}$ From March 2014, the band was increased further to $+/-2$ per cent. Officially, the exchange rate is deemed to be freely floating within this trading band, with the $\mathrm{PBC}$ intervening to maintain the band. If movements of around 2 per cent per day relative to the previous trading day's spot rate were permitted, this would amount to a degree of exchange rate flexibility that is similar to most countries with floating exchange rates; however, as the band is defined relative to a reference rate set by the authorities each trading day, the central bank retains considerable control over the direction of movements in the exchange rate.

Steady development of the onshore foreign exchange market over the past decade has seen growing use of instruments to hedge foreign currency exposure. Prior to the mid 2000s, only spot foreign exchange transactions could occur on the CFETS. In 2005 foreign exchange (deliverable) forwards were introduced; foreign exchange swaps were introduced in 2006 (Xie 2009:476), and now record monthly turnover comparable with that of the spot market. However, the lack of volatility in the exchange rate, restrictions on the use of foreign currency in China and controlled access to offshore markets have limited the depth and liquidity of these hedging markets.

Official efforts have been made to 'internationalise' the currency in recent years, allowing a pool of renminbi to accumulate offshore where it is freely tradeable (subject to local regulations). This has facilitated the development of a range of offshore renminbi-denominated financial products, including foreign exchange products and hedging tools. The internationalisation process has the potential to bring significant benefits to Chinese firms. As international trade is increasingly denominated in renminbi, firms may be better able to reduce currency mismatches on their balance sheets, mitigating vulnerabilities that could arise as the exchange rate becomes more flexible. Another possible advantage is that as capital account liberalisation proceeds, the entry of nonresidents to China's domestic financial markets will increase the depth of these markets, increasing the availability of counterparties for Chinese entities seeking to hedge their foreign currency liabilities (Lowe 2014).

25 Having effectively pegged the renminbi against the US dollar since 2008, in June 2010 the PBC announced that it would allow increased flexibility in the exchange rate, managing the renminbi against an unspecified basket of currencies. 


\section{Comparing financial reform in Australia and China}

In some respects, China is now facing a similar set of policy challenges on its path towards financial liberalisation to those faced by Australia in the late 1970s and early 1980s. These include challenges currently posed by China's domestic financial system, including the rapid growth of financing channels outside a tightly regulated banking sector, and concerns about firms' ability to insure against increased exchange rate volatility. These challenges have led some observers (such as Yu 2013) to emphasise the risks of a rapid reduction in China's capital controls; however, the reforms currently under way in China are taking place in a very different domestic and global context to those which took place in Australia and, to an extent, these differences have been reflected in the contrasting approaches to reform taken in the two countries.

\section{The context of reform}

The global economy and financial system are much more interconnected today than they were 30 years ago. Australia's capital account and financial reform process began in the context of a breakdown in the Bretton Woods system and the very early stages of global financial integration. The combination of a fixed exchange rate regime, rising cross-border capital flows and the expansion of the NBFI sector made it increasingly challenging for the Australian authorities to control domestic monetary conditions.

Both China up to the late 1990s and Australia up to the float imposed asymmetric capital controls, with tighter restrictions on residents' investment abroad than on foreign investment in their domestic economies, and relatively relaxed policies towards FDI inflows in particular; however, Australia's capital account prior to 1983 was probably more open with respect to non-FDI inflows than China's is today (Figure 11.13). ${ }^{26}$ The greater integration of the modern global financial system, larger global capital markets and a relatively low starting point in terms of non-FDI inflows all suggest that, in the event of capital account liberalisation, China will be exposed to a more substantial increase in capital flows than Australia faced in the early 1980s.

26 To some extent, the initial openness of Australia's capital account with respect to portfolio flows reflected the smaller role such flows had played in the global and Australian economies prior to the 1970s. 
4-year average; share of total

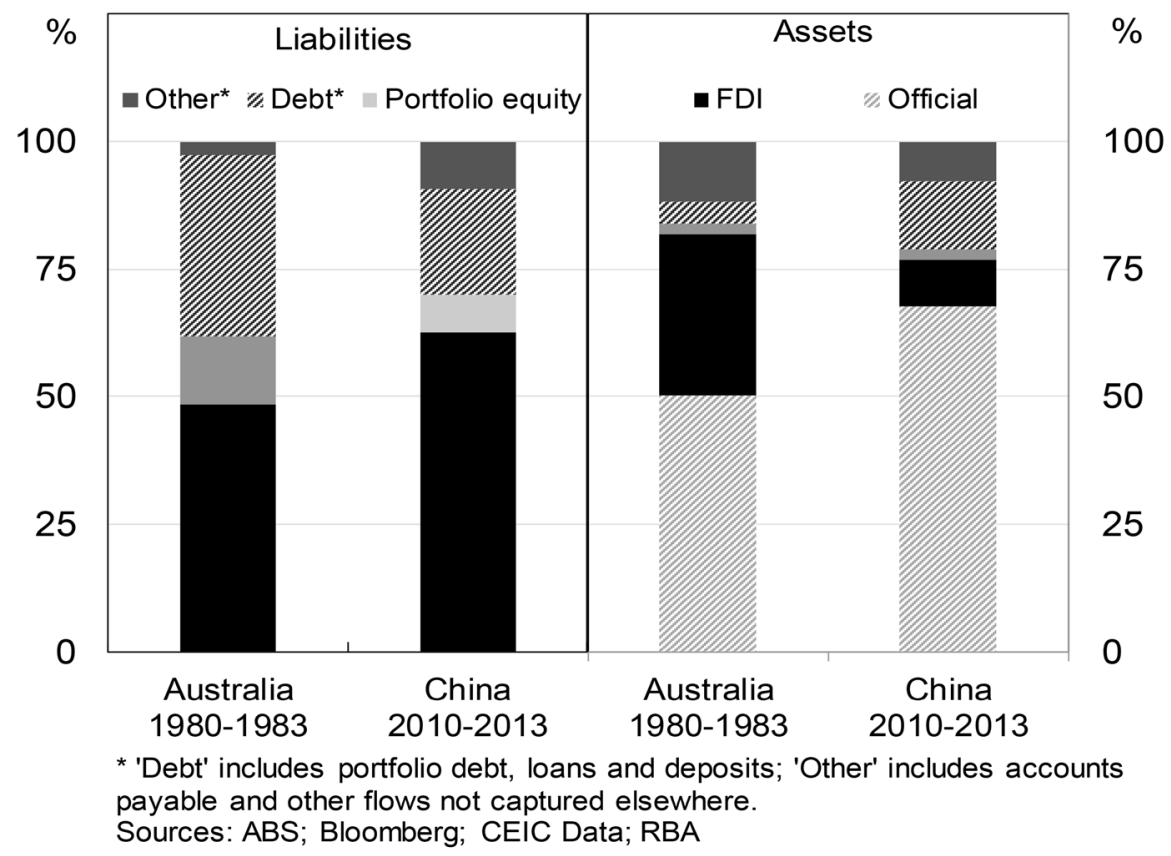

Figure 11.13 Australian and Chinese Gross External Positions

Sources: Australian Bureau of Statistics (ABS), Bloomberg, CEIC data at <http://dev.ceicdata.securities. com/about_ceic.html>; The Reserve Bank of Australia (RBA).

Notes: 'Debt' includes portfolio debt, loans and deposits; 'other' includes accounts payable and other flows not captured elsewhere.

The size and volatility of these flows may be amplified by China's already significant role in the global financial system-something Australian policymakers did not have to contend with in the early 1980s. At the time of the float, Australia was a relatively minor participant in global financial markets. Thus, there was little 'feedback' between financial developments in Australia and the global system. In contrast, the Chinese economy and financial sector are much larger than Australia's were at the time of liberalisation. In 1983, total assets of the Australian financial sector were 1.3 times the value of GDP, whereas in 2013, the value of the Chinese financial sector's total assets amounted to 2.7 times GDP. Scaled by the size of the Chinese economy, this implies that the liberalisation of China's capital account and financial sector is likely to be accompanied by a substantial increase in the size of inward and outward crossborder capital flows, and so will have significant spillover effects on global capital markets. 
The size of China's economy and financial sector could provide some ballast against these flows, by providing China with more capacity to absorb speculative capital. In addition, China's large foreign exchange reserves, which were around 40 per cent of GDP in 2013, could provide a buffer against the impact of global capital flows (Australia's foreign exchange reserves were less than 5 per cent of GDP in 1983).

Notwithstanding these considerations, a more open capital account could still be a source of instability if the process is not carefully managed. For example, similar to Australia, in China, the recent rapid growth of the nonbank sector has posed challenges for the authorities in their control of aggregate financing flows. Such challenges are likely to be compounded by any surge in cross-border capital inflows and outflows.

\section{The approach to liberalisation}

The different starting points are partly reflected in the different roads to liberalisation taken by Australia and China. Australia's capital account and financial liberalisation were ultimately prompted by sizeable external pressures that were placed on the economy by the increasing integration of world financial flows, coupled with Australia's relatively open capital account and small (economic) size. The sequencing of reform in Australia prior to the float featured a series of currency regimes (a peg to the UK pound, a peg to the US dollar, a peg to a TWI and a crawling peg to a TWI), the removal of deposit rate ceilings prior to those for lending rates, and a gradual easing of financial sector and capital controls (albeit with the reimposition of some controls when the effects became severe). Contrary to the advice of one line of the academic literature on 'sequencing', at the time of the float the work of banking sector deregulation was only partly complete, and Australia lacked credible frameworks for macroeconomic policy and prudential regulation. ${ }^{27}$

Nonetheless, Australia's approach to reform was not entirely 'reactive'. The Australian authorities had in most cases given advance thought to the need for reform and the manner of its implementation. Documents from the era, and the commissioning of the Campbell Committee inquiry into financial sector deregulation in the late 1970s, indicate that a considerable amount of planning went into reforming Australia's capital account and financial system (Cornish 2010: ch. 7). A characteristic of the Australian approach was, however, that the actual decisions to implement reform were often taken relatively quickly, and in response to external changes that exposed weakness in the existing system.

27 For example, while the RBA had powers to act if it appeared that deposits were in jeopardy, it was not given formal supervisory powers until 1989 (Thompson 1991). 
The approach to financial reform taken by the People's Republic of China has, since the early 2000s (and implicitly since the mid 1990s), been characterised by a stated objective of eventual interest rate, exchange rate and capital account liberalisation. China's reform path first involved implementing partial reforms via pilot programs before expanding their scope and/or scale. The Australian authorities also used this approach to an extent-for example, removing interest rate ceilings for certificates of deposit prior to the removal of all deposit rate ceilings. In comparison, the Chinese approach to interest rate reform has emphasised tightly controlled pilots to increase the flexibility of various types of interest rates offered by different financial institutions, in some cases to specific classes of enterprises.

The difference in approach is especially noticeable in efforts to increase the flexibility of the exchange rate and open the capital account - for example, the staged widening of the renminbi's daily trading band against the US dollar since 2005, and staggered increases in quotas controlling the size of the QFII and RQFII programs. Domestic financial reforms have occurred in tandem with incremental efforts to improve currency flexibility, but to avoid destabilising outcomes, reforms to controls of portfolio flows have been particularly gradual.

Where risks have been encountered in China, as was the case with early efforts to increase the flexibility of deposit rates, the banking sector stress of the late 1990s and the threat posed to exchange rate stability by the Asian financial crisis, the Chinese authorities have usually responded by slowing the pace of deregulation. To some extent this has been facilitated by China's controls on portfolio capital flows, which have given policymakers an additional degree of flexibility in pursuing domestic financial reform by providing a buffer against external pressures. ${ }^{28}$ In contrast, through the 1970s and early 1980s, Australian authorities were ultimately forced by the size of short-term speculative flowsand the resulting constraints on domestic monetary policy-to float the exchange rate.

\section{Post-reform challenges}

A feature of Australia's financial reform process was the interaction between financial sector development and capital account liberalisation. In particular, the Australian experience suggests there is the potential for positive feedback loops to develop once the process has begun (Lowe 2014). Two concrete examples of

28 While differences in political and administrative arrangements in the two countries are no doubt also important in explaining the differences in approach, such considerations are beyond the scope of this chapter. 
this are prudential regulation and foreign exchange hedging markets, neither of which fully developed in Australia until some time after liberalisation had taken place.

The post-float boom and bust in credit and commercial property prices in Australia revealed the relative inexperience of financial institutions and regulators in forming risk assessments about borrowers. These skills were learned as a result of painful adjustment to the realities of the newly deregulated environment. The episode supports the arguments of Fry (1997), Johnston (1998) and Mishkin (2001) that, ideally, a good prudential supervision framework should be established before the financial sector and capital account are liberalised to mitigate risks to financial stability. It also highlights, however, the fact that it can be difficult to develop such a framework in the context of a highly regulated system that is not exposed to risk-taking behaviour (Lowe 2013).

In some respects, China's prudential framework could be considered more advanced than Australia's was before the float of the dollar. The late-1990s NPL crisis and subsequent recapitalisation of the banking system helped focus official attention on prudential regulation in the early 2000s. Significant progress has been made in introducing modern commercial banking practices to Chinese banks and the banking regulator has been active in strengthening banks' provision and capital buffers (Huang et al. 2013:132; Turner et al. 2012). The widespread perception that loans to SOEs have an implicit state guaranteenotwithstanding concerns about the quality of some of these assets - and the incomplete nature of interest rate deregulation may, however, still hinder the accurate pricing of risk by financial institutions. It may be hard for Chinese banks and regulators to develop risk-management capabilities fully prior to the transition to a system that lacks these guarantees and in which interest rates can move freely.

A similar example can be found in the development of hedging markets. For Australia, a deep and liquid foreign exchange derivatives market has, over time, proven crucial for allowing residents to access overseas funds while effectively managing their currency and interest rate exposure. Despite the development of an unofficial onshore foreign currency hedging market by the private sector prior to the float of the Australian dollar, the decision to reform the currency regime was the primary catalyst for the emergence of modern hedging markets and practices.

In China, the authorities have to date played a more direct role in fostering the development of hedging practices than Australia prior to the float. Reforms in the mid 2000s introduced foreign exchange derivatives and over-the-counter trading of the renminbi. More recently, the authorities' efforts to create offshore markets for the renminbi have accelerated the development of foreign exchange 
products, and helped lay the groundwork for an eventual loosening of capital controls. These offshore markets have the potential to increase the pool of future market participants by creating non-resident counterparties with renminbi exposures they may wish to hedge.

Recent moves by the PBC to bolster two-way volatility in the exchange rate could also lead participants to make greater use of onshore hedging markets. Naturally, the depth and liquidity of the market continue to be constrained by the managed exchange rate regime and capital controls, which restrict the interaction of onshore and offshore market participants - even more so than was the case for Australia prior to the float (Figure 11.14). The foundations that are already in place-including global and domestic market expertise and infrastructure, and the availability of a relatively broad range of potential hedging instruments - suggest, however, that China's hedging markets could develop quickly once the current restrictions are removed, as they did in Australia.

Ratio to gross quarterly trade and non-reserve capital flows

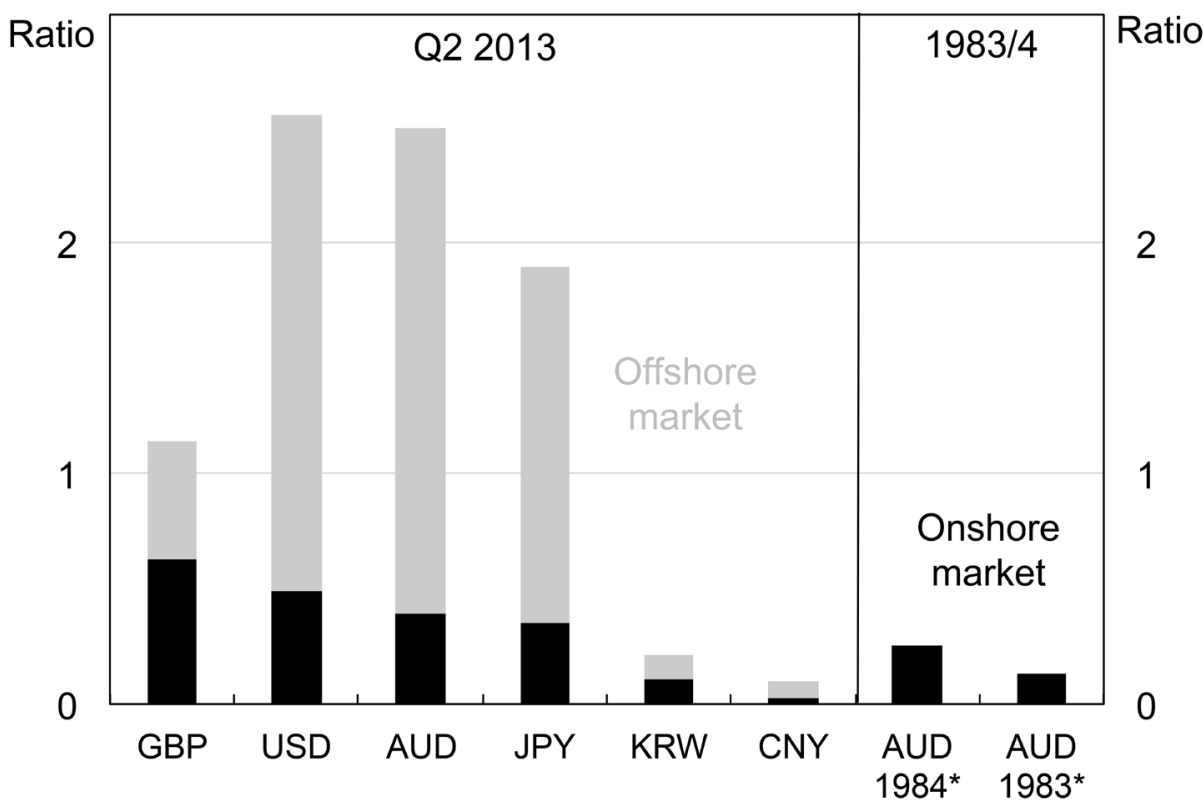

Figure 11.14 Average Daily Turnover in Selected Foreign Exchange Markets

* Post-float (1984) observation taken as at September; pre-float (1983) observation taken as at November. Sources: Australian Bureau of Statistics (ABS); Bank of International Settlement (BIS); Phillips (1984a); CEIC data at <http://dev.ceicdata.securities.com/about_ceic.html>; The Reserve Bank of Australia (RBA). 


\section{Concluding remarks}

China today faces markedly different domestic and global circumstances than Australia did in the late 1970s and early 1980s. The relevance of the Australian example for China is that it underscores the potential catalytic effects of a decision to liberalise financial development. Moreover, it suggests that the full benefits of a complete financial deregulation-encompassing deregulated interest rates, an open capital account and a floating exchange rate-may be felt only once the system has adapted to changed arrangements and the credibility of the post-reform policy framework and institutions has been established.

The specific sequencing of deregulation that occurred in Australia might not be optimal in a Chinese context. In several respects, China is now at a more advanced stage of reform than Australia was in the late 1970s, particularly with respect to the development of its financial system, including its hedging markets and prudential framework. Broadly speaking, the Australian experience has tended to support the conclusions of Johnston (1998) and Ishii and Habermeier (2002) - namely, that reform creates its own momentum. Domestic financial deregulation can create additional channels for capital flows, making capital controls less effective and creating pressure for their removal. By the same token, capital account liberalisation may increase the urgency of broader financial sector reforms to deal with the increased capital flows. Either way, the path to reform is not without its risks and the stakes are undoubtedly higher for China (and the world) today than they were for Australia in the early 1980s.

\section{References}

Allen, F., Qian, Q. J., Zhang, C. and Zhao, M. (2012), China's financial system: opportunities and challenges, NBER Working Paper No. 17828, National Bureau of Economic Research, Cambridge, Mass.

Atkin, T., Caputo, M., Robinson, T. and Wang, H. (2014), Macroeconomic consequences of terms of trade episodes, past and present, RBA Research Discussion Paper No. 2014-01, Reserve Bank of Australia, Sydney.

Australian Treasury (1999), 'Australia's experience with the variable deposit requirement', Economic Roundup (Winter): 45-56.

Battellino, R. (2007), Australia's experience with financial deregulation, Address to the China Australia Governance Program, Melbourne, 16 July 2007. Available from <http://www.rba.gov.au/speeches/2007/sp-dg-160707.html>. 
Battellino, R. and McMillan, N. (1989), Changes in the behaviour of banks and their implications for financial aggregates, RBA Research Discussion Paper No. 8904, Reserve Bank of Australia, Sydney.

Battellino, R. and Plumb, M. (2011), 'A generation of an internationalised Australian dollar', in A. Filardo and J. Yetman (eds), Currency internationalisation: lessons from the global financial crisis and prospects for the future in Asia and the Pacific, BIS Papers No. 61, pp. 202-17, Bank for International Settlements, Basel.

Beaumont, C. and Cui, L. (2007), Conquering fear of floating-Australia's successful adaptation to a flexible exchange rate, IMF Policy Discussion Paper No. 07/2, International Monetary Fund, Washington, DC.

Becker, C. and Fabbro, D. (2006), Limiting foreign exchange exposure through hedging: the Australian experience, RBA Research Discussion Paper No. 200609, Reserve Bank of Australia, Sydney.

Becker, C. and Sinclair, M. (2004), Profitability of Reserve Bank foreign exchange operations: twenty years after the float, RBA Research Discussion Paper No. 2004-06, Reserve Bank of Australia, Sydney.

Bonin, J. P. and Huang, Y. (2001), 'Dealing with the bad loans of the Chinese banks', Journal of Asian Economics 12(2): 197-214.

Chinese Communist Party (CCP) (2013), Decisions by the Central Committee of the Chinese Communist Party on Several Large Questions Concerning the Comprehensive Deepening of Reform, Beijing: Readings on Party Construction Publishing House.

Cornish, S. (2010), The Evolution of Central Banking in Australia, Sydney: Reserve Bank of Australia.

Davies, R., Katinaite, K., Manning, M. and Richardson, P. (2010), 'Evolution of the UK banking system', Bank of England Quarterly Bulletin (December): $321-32$.

Debelle, G. and Plumb, M. (2006), 'The evolution of exchange rate policy and capital controls in Australia', Asian Economic Papers 5(2): 7-29.

Eichengreen, B., Walsh, K. and Weir, G. (2014), Internationalisation of the renminbi: pathways, implications and opportunities, CIFR Research Report, March, Centre for International Finance and Regulation, Sydney. Available from <http:/ www.cifr.edu.au/assets/document/CIFR \% 20Internationalisation \% 20of\% 20 the \%20RMB\%20Report\%20Final\%20web.pdf>. 
Fry, M. J. (1997), 'In favour of financial liberalisation', Economic Journal 107 (May): 754-70.

Gizycki, M. and Lowe, P. (2000), 'The Australian financial system in the 1990s', in D. Gruen and S. Shrestha (eds), The Australian Economy in the 1990s, pp. 180-215, Sydney: Reserve Bank of Australia.

Government of the People's Republic of China (2005), Summary of the Eleventh Five-Year Guideline for National Economic and Social Development, Beijing. Available from <http://www.qibebt.cas.cn/kxcb/kpwz/nyzcgh/200906/ P020090630584175269777.pdf $>$.

Government of the People's Republic of China (2011), Summary of the Twelfth Five-Year Guideline for National Economic and Social Development, Beijing. Available from <http:/ghs.ndrc.gov.cn/ghwb/gjwngh/201109/ P020110919590835399263.pdf $>$.

Grenville, S. (1991), 'The evolution of financial deregulation', in I. Macfarlane (ed.), The Deregulation of Financial Intermediaries, pp. 3-35, Sydney: Reserve Bank of Australia.

Guo, J. (2013), 'Interest rate marketisation and the interest rate pricing mechanism', China Finance, republished by Sina Finance. Available from $<$ http://finance.sina.com.cn/money/bond/20131118/095417352836.shtml>.

He, F. (2013), 'Reform in a time of slowing growth', China Finance, republished by Sina Finance. Available from <http://finance.sina.com.cn/money/bank/ bank_hydt/20130516/134615487270.shtml>.

$\mathrm{Hu}, \mathrm{X}$. (2010), A managed floating exchange rate regime is an established policy, Speech given by People's Bank of China Deputy Governor, $\mathrm{Hu}$ Xiaolian, 15 July. Available from <http://www.pbc.gov.cn/publish/ english/956/2010/20100727144152118668062/20100727144152118668062_. html>.

Huang, Y., Wang, X., Wang, B. and Lin, N. (2013), 'Financial reform in China: progress and challenges', in Y. C. Park and H. Patrick (eds), How Finance is Shaping the Economies of China, Japan, and Korea, pp. 44-142, New York: Columbia University Press.

Ishii, S. and Habermeier, K. (2002), Capital account liberalization and financial sector stability, IMF Occasional Paper No. 232, International Monetary Fund, Washington, DC. 
Johnston, B. (1998), Sequencing capital account liberalization and financial reform, IMF Paper on Policy Analysis and Assessment No. PPAA/98/8, International Monetary Fund, Washington, DC.

Laker, J. (1988), Exchange rate policy in Australia, Paper presented at the 17th South East Asia, New Zealand and Australia Central Banking Course, Sydney, 2 November.

Lardy, N. R. (1998), China's Unfinished Economic Revolution, Washington, DC: Brookings Institution Press.

Lardy, N. R. (2002), Integrating China into the Global Economy, Washington, DC: Brookings Institution Press.

Le, J. (2007), 'China's bond market', in S. N. Neftci and M. Y. Ménager-Xu (eds), China's Financial Markets: An Insider's Guide to How the Markets Work, pp. 137-70, New York: Elsevier.

Lowe, P. (2013), The journey of financial reform, Address to the Australian Chamber of Commerce in Shanghai, Shanghai, 24 April. Available from <http://www.rba.gov.au/speeches/2013/sp-dg-240413.html>.

Lowe, P. (2014), Some implications of the internationalisation of the renminbi, Opening remarks to the Centre for International Finance and Regulation Conference on the Internationalisation of the Renminbi, Sydney, 26 March. Available from <http://www.rba.gov.au/speeches/2014/sp-dg-260314.html>.

Ma, G., Yan, X. and Liu, X. (2011), China's evolving reserve requirements, BIS Working Paper No. 360, Bank for International Settlements, Basel.

McCauley, R. (2006), 'Internationalising a currency: the case of the Australian dollar', BIS Quartely Review (December): 41-54.

McKinnon, R. (1982), 'The order of economic liberalization: lessons from Chile and Argentina', in Carnegie-Rochester Conference Series on Public Policy. Volume 17, pp. 159-86, Amsterdam: North-Holland.

McKinnon R. (1991), 'Financial control in the transition from classical socialism to a market economy', Journal of Economic Perspectives 5(4): 107-22.

McKinnon, R. (1994), 'Financial growth and macroeconomic stability in China, 1978-1992: implications for Russia and other transitional economies', Journal of Comparative Economics 18: 438-69.

Manuell, G. (1986), Floating Down Under: Foreign Exchange in Australia, Sydney: The Law Book Company Limited. 
Mishkin, F. S. (2001), Financial policies and the prevention of financial crises in emerging market countries, NBER Working Paper No. 8087, National Bureau of Economic Research, Cambridge, Mass.

Newman, V., Potter, C. and Wright, M. (2011), 'Foreign exchange market intervention', Reserve Bank of Australia Bulletin (December): 67-76.

People's Bank of China (PBC) (1999), Almanac of China's Finance and Banking 1999, Beijing: People's China Publishing House.

People's Bank of China (PBC) (2000), Almanac of China's Finance and Banking 2000, Beijing: People's China Publishing House.

People's Bank of China (PBC) (2003), 2002 Monetary Policy Report, Beijing: People's China Publishing House.

People's Bank of China (PBC) (2005), Report on gradually pushing forward interest rate marketisation, People's Bank of China, Beijing. Available from <http:// www.pbc.gov.cn/publish/zhengcehuobisi/606/1276/12766/12766_.html>.

People's Bank of China (PBC) (2014), 'People's Bank of China Governor Zhou Xiaochuan responds to journalists' questions regarding "financial reform and development", 26 March, People's Bank of China, Beijing. Available from <http://www.pbc.gov.cn/ publish/goutongjiaoliu/524/2014/20140311120919964302085/ 20140311120919964302085_.html>.

People's Bank of China (PBC) Department of Surveys and Statistics Task Force (2012a), The conditions for accelerating the opening of the capital account are basically mature, People's Bank of China, Beijing. Available from $<$ http://www. pbc.gov.cn/publish/diaochatongjisi/866/2012/20120523135503424585606/ 20120523135503424585606_.html>.

People's Bank of China (PBC) Department of Surveys and Statistics Task Force (2012b), Push forward interest rate and exchange rate reform and capital account opening in harmony, People's Bank of China, Beijing. Available from $<$ http://economy.caijing.com.cn/2012-04-17/111815022.html>.

Phillips, M. J. (1984a), ...Now for 1985, Address to the Australian Forex Association Second Annual Conference, Canberra, 10 November.

Phillips, M. J. (1984b), Financial reform - the Australian experience, Address to the Pacific Basin Financial Reform Conference, Federal Reserve Bank of San Francisco, San Francisco, 2-5 December. 
Phillips, M. J. (1985), Policy on exchange rates and foreign exchange controls since the late 1960s, Address to the Australian Shippers' Council Shipper/ Exporter Workshops, April-May.

Prasad, W. E. and Wei, S.-J. (2005), The Chinese approach to capital inflows: patterns and possible explanations, IMF Working Paper No. WP/05/79, International Monetary Fund, Washington, DC.

Prasad, W. E., Rumbaugh, T. and Wang, Q. (2005), Putting the cart before the horse? Capital account liberalization and exchange rate flexibility in China, IMF Policy Discussion Paper No. PDP/05/1, International Monetary Fund, Washington, DC.

Rush, A., Sadeghian, D. and Wright, M. (2013), 'Foreign currency exposure and hedging in Australia', Reserve Bank of Australia Bulletin (December): 49-58.

Stevens, G. (2013), The Australian dollar: thirty years of floating, Speech to the Australian Business Economists' Annual Dinner, Sydney, 21 November. Available from < http://www.rba.gov.au/speeches/2013/sp-gov-211113.html>.

Stevens, G., Kent, C. and Cagliarini, A. (2010), 'Fifty years of monetary policy: what have we learned?', in C. Kent and M. Robson (eds), Reserve Bank of Australia 50th Anniversary Symposium, Sydney: Reserve Bank of Australia.

Tan, W. (2007), 'A history of China's stock markets', in S. N. Neftci and M. Y. Ménager-Xu (eds), China's Financial Markets: An Insider's Guide to How the Markets Work, pp. 215-36, New York: Elsevier.

Thompson, G. (1991), 'Prudential supervision', in I. Macfarlane (ed.), The Deregulation of Financial Intermediaries, pp. 115-42, Sydney: Reserve Bank of Australia.

Turner, G., Tan, N. and Sadeghian, D. (2012), 'The Chinese banking system', Reserve Bank of Australia Bulletin (September): 53-63.

Xie, D. (2009), 'China's money, bond and FX markets', in M. Zhu, J. Cai and M. Avery (eds), China's Emerging Financial Markets: Challenges and Global Impact, pp. 459-80, Singapore: Wiley.

Yi, G. (2008), 'Renminbi exchange rates and relevant institutional factors', Cato Journal 28(2): 187-96.

Yi, G. (2009), 'The thirty year course of interest rate marketisation in China's period of reform and opening', Financial Research 343(1): 1-14. 
Yu, Y. (2013), The temptation of china's capital account, 27 March. Available from <http://www.project-syndicate.org/commentary/the-risks-of-easingchina-s-capital-controls-by-yu-yongding $>$.

Zheng, X. (2007), 'China's money markets', in S. N. Neftci and M. Y. Ménager$\mathrm{Xu}$ (eds), China's Financial Markets: An Insider's Guide to How the Markets Work, pp. 41-86, New York: Elsevier.

Zhou, X. (2005), 'Thoughts on financial system reforms in the period of the eleventh five-year plan', Study Times 311, reprinted by Xinhua. Available from $<$ http://news.xinhuanet.com/politics/2005-11/18/content_3798040.htm>.

Zhou, X. (2013), 'Comprehensive deepening of financial industry reform and opening: accelerating the improvement of the financial market system', in Chinese Communist Party, Decisions by the Central Committee of the Chinese Communist Party on Several Questions Concerning the Comprehensive Deepening of Reform, pp. 145-56, Beijing: Readings on Party Construction Publishing House. 
This text taken from Deepening reform for China's long-term growth and development, edited by Ligang Song, Ross Garnaut, Cai Fang, published July 2014 by ANU Press, The Australian National University, Canberra, Australia. 